Simulasi Dampak Perubahan Tutupan

Lisa Tanika, Betha Lusiana, Adis Hendriatna \title{
Lahan dan Iklim di DAS Citarum Hulu dengan Model GenRiver: Kalibrasi model \\ dan analisa sensitivitas
}





\section{Simulasi Dampak Perubahan Tutupan Lahan dan Iklim di DAS Citarum Hulu dengan Model GenRiver: Kalibrasi model dan analisa sensitivitas}




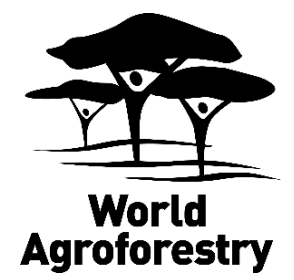

Correct citation

Tanika L, Lusiana B, Hendriatna A. 2020. Simulasi Dampak Perubahan Tutupan Lahan dan Iklim di DAS Citarum Hulu dengan Model GenRiver: Kalibrasi model dan analisa sensitivitas. Working paper no. 309. Bogor, Indonesia: World Agroforestry (ICRAF) Southeast Asia Regional Program. DOI:

http://dx.doi.org/10.5716/WP20048.PDF

Titles in the Working Paper series disseminate interim results on agroforestry research and practices to stimulate feedback from the scientific community. Other publication series from the World Agroforestry include agroforestry perspectives, technical manuals and occasional papers.

Published by World Agroforestry

Southeast Asia Regional Program

PO Box 161, Bogor 16001

Indonesia

Tel: +622518625415

Fax: +622518625416

Email: icraf-indonesia@cgiar.org

Website: http://worldagroforestry.org/regions/SEA

(C) World Agroforestry 2020

Working Paper no. 309

\section{Photographs:}

The views expressed in this publication are those of the author(s) and not necessarily those of the World Agroforestry Articles appearing in this publication may be quoted or reproduced without charge, provided the source is acknowledged. All images remain the sole property of their source and may not be used for any purpose without written permission of the source. 


\section{Tentang Penulis}

Lisa Tanika bergabung dengan World Agroforestry pada tahun 2008 hingga 2017 sebagai seorang ahli model ekologi. Lisa berlatar belakang pendidikan S1 Matematika dan S2 Klimatologi Terapan dari Institut Pertanian Bogor dan saat ini sedang mengikuti program S3 di Universiats Wageningen, Belanda. Riset yang ia tekuni berfokus pada pemanfaatan model Generic River Flow (GenRiver) untuk menganalisis fungsi DAS, khususnya untuk mengetahui dampak perubahan tutupan lahan dan perubahan iklim terhadap keseluruhan funsgsi hidrologi sebuah DAS. Lisa menaruh minat yang besar terhadap pengembangan dan penerapan pendekatan partisipatoris bagi para pemangku kepentingan terkait dalam memonitor fungsi DAS.

Betha Lusiana adalah peneliti World Agroforestry di bidang pemodelan ekologi. Gelar doktor diperolehnya dari Universitas Hohenheim University dengan kajian pemanfaatan model dalam pengelolaan sumber daya alam. Selama ini, penelitiannya berfokus pada trade-offs antara pengembangan pertanian, khususnya agroforestry dengan penghidupan petani dan dan jasa lingkungan dengan menggunakan simulasi model atau pendekatan kuantitatif yang partisipatoris. Selain itu, Betha menaruh minat pada pengembangan kapasitas peneliti di bidang pemodelan dan pendekatan kuantitatif lainnya, seperti metode statistik untuk mengevaluasi fungsi jasa lingkungan bentang alam.

Adis Hendriatna adalah asisten penginderaan jauh \& GIS di ICRAF sejak tahun 2018. Adis memiliki latar belakang pendidikan analisa lingkungan dan GIS dalam pendidikan S1 Kehutanan di Institut Pertanian Bogor dan telah berpengalaman lebih dari 8 tahun bekerja sama dengan tim ilmuwan multidisiplin, terutama dibidang spesialis penginderaan jauh, perubahan iklim, pertumbuhan hijau, dan analisa penggunaan lahan. Adis juga aktif dalam membangun beberapa tools berbasis GIS dan terlatih melakukan kegiatan lapangan baik menggunakan GPS maupun drone (pemetaan udara). 


\section{Abstrak}

Alih guna lahan dan perubahan iklim merupakan faktor-faktor yang dapat mempengaruhi kondisi hidrologi di suatu Daerah Aliran Sungai (DAS), dan yang dapat mempengaruhi efektifitas fungsi DAS dalam mempertahankan keseimbangan neraca air di tingkat bentang alam. Oleh karena itu pengelolaan DAS yang didukung dengan perencanaan DAS terpadu yang juga mengatur peruntukan dan pemafaatan wilayah sangat diperlukan. Langkah awal dalam perencanaan DAS adalah dengan menilai kondisi fungsi hidrologi DAS tersebut dengat tujuan mengetahui apakah DAS mulai atau telah mengalami degradasi, atau sebaliknya mulai mengalami perbaikan fungsi DAS. Model simulasi seperti model Genriver dapat digunakan menilai kondisi saat ini serta memproyeksikan bagaimana dampak perubahan lahan dan iklim terhadap kondisi hidrologis DAS. Salah satu DAS penting di Jawa Barat adalah DAS Citarum Hulu sebagi bagian dari DAS Citarum yang telah ditetapkan sebagai salah satu DAS prioritas nasional. Kalibrasi model dan analisis sensitivitas menjadi bagian penting untuk mengetahui kelayakan suatu model hidrologi dalam mensimulasikan kondisi DAS, khususnya dalam mengestimasi neraca air di tingkat lansekap. Hasil kalibrasi model GenRiver dengan menggunakan data tahun 2012-2016 menunjukkan bahwa parameterisasi model telah berhasil dan model layak digunakan untuk analisa sensitivitas dan simulasi skenario. Hasil simulasi model, menunjukan bahwa secara rata-rata $37 \%$ curah hujan yang jatuh di DAS Citarum Hulu menjadi aliran permukaan (surface flow/run-off), $7 \%$ menjadi aliran bawah permukaan (sub-surface flow) dan 20\% menjadi aliran dasar (baseflow). Analisa senssitivitas dilakukan dengan menyusun lima skenario tutupan lahan dan tiga skenario curah hujan yang dianggap mewakili berbagai kondisi yang mungkin termasuk kondisi ekstrim: yaitu keseluruhan lahan menjadi area terbuka (ekstrim negatif) dan seluruh lahan menjadi hutan (ekstrim positif). Hasil proyeksi simulasi ekstrim negatif menunjukan bahwa kondisi DAS Citarum Hulu yang terdegradasi dengan dominasi lahan terbuka berpotensi meningkatkan aliran permukaan hingga mencapai 70\% dari curah hujan. Sedangkan perbaikan tutupan lahan DAS Citarum hulu dengan reforestasi (skenario ekstrim positif) mampu menurunkan aliran permukaan hingga mencapai $20 \%$ dari total curah hujan.

\section{Kata Kunci}

Analisis sensitivitas, DAS Citarum, model hidrologi, model Genriver, fungsi hidrologi DAS, dampak perubahan lahan dan iklim 


\section{Ucapan Terima kasih}

Studi in didanai oleh ACIAR melalui proyek 'Agricultural Policy Research to Support Natural Resource Management in Indonesia's Upland Landscapes - ADP/2015/043'. Kami mengucapkan terimakasih kepada the Indonesian Centre for Agriculture Socio-Economic and Policy Studies (ICASEPS) yang telah memfasilitasi penyediaan pendanaan tersebut. Teknik penilaian hidrologis menggunakan model GenRiver beserta hasil kalibrasi dan analisa sensitivitas di DAS Citarum Hulu telah dipaparkan pada pelatihan di bulan Desember 2019 yang diselenggarakan oleh ICASEPS. Penulis mengucapkan terimakasih kepada peserta pelatihan atas masukan yang diberikan selama pelatihan, khususnya kepada Dr. Ir. Erwidodo, MS dan Henri Wira Perkasa MSc. 


\section{Daftar Isi}

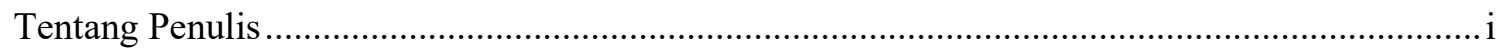

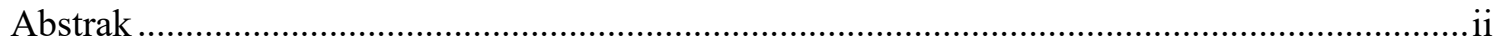

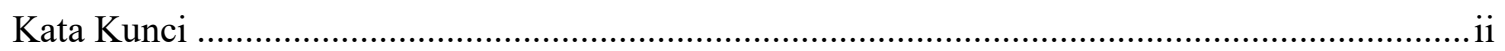

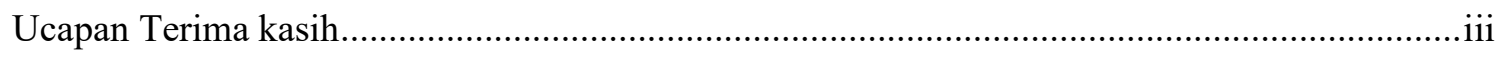

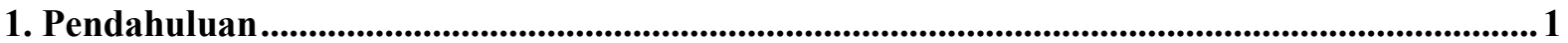

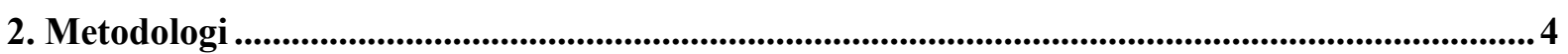

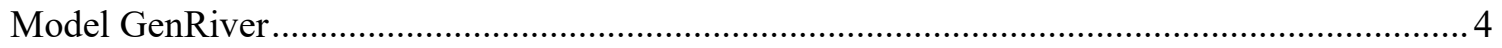

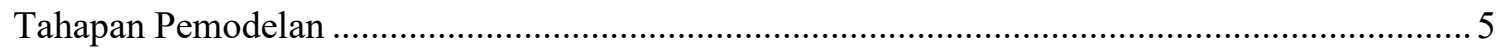

Kalibrasi, Analisa Sensitivitas dan Evaluasi Model.................................................................. 7

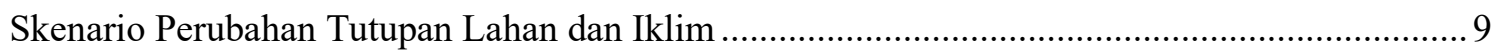

3. Karakteristik Lokasi Penelitian..............................................................................................................11

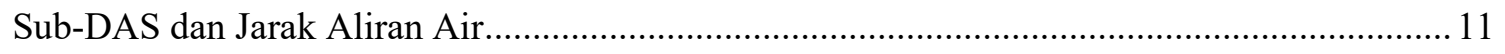

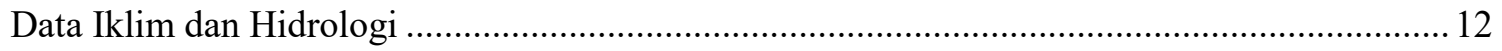

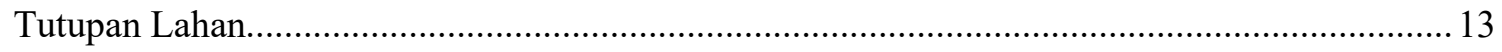

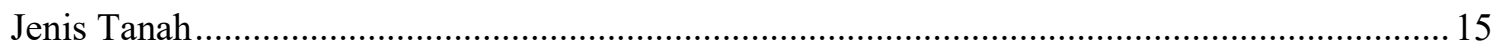

4. Uji kesesuaian data iklim dan hidrologi ...........................................................................................16

5. Hasil dan Pembahasan ................................................................................................................................... 17

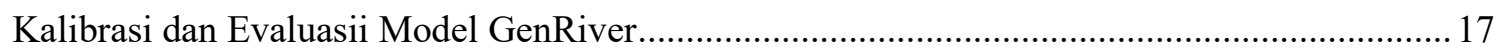

Simulasi Dampak Perubahan Tutupan Lahan terhadap Kondisi DAS Citarum Hulu

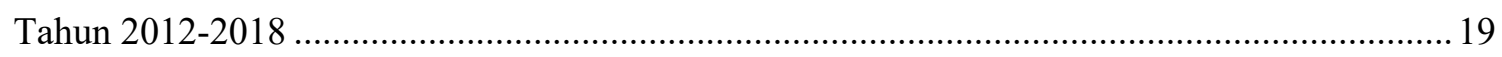

Simulasi Skenario Perubahan Tutupan Lahan dan Iklim Terhadap Kondisi DAS

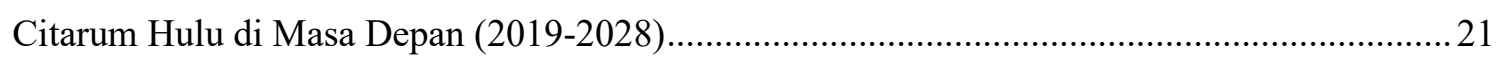

6. Kesimpulan dan Rekomendasi ................................................................................................................25

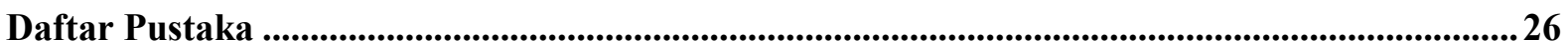




\section{Daftar Tabel}

Tabel 1. Data minimum yang diperlukan untuk mensimulasikan Model GenRiver ..............................5

Tabel 2. Acuan kinerja model dalam memprediksi debit sungai berdasarkan nilai bias........................8

Tabel 3. Acuan kinerja model dalam memprediksi debit sungai berdasarkan nilai NSE......................9

Tabel 4. Skenario perubahan tutupan lahan dan iklim di DAS Citarum Hulu ......................................9

Tabel 3. Luas area dan jarak routing masing-masing Sub-DAS di DAS Citarum Hulu ......................12

Tabel 4. Luas area masing-masing jenis tutupan lahan di DAS Citarum Hulu...................................14

Tabel 5. Hasil parameterisasi Model GenRiver untuk DAS Citarum Hulu .......................................17

Tabel 6. Hasil Kalibrasi dan validasi Model GenRiver untuk DAS Citarum Hulu..............................18

Tabel 7. Kondisi neraca air DAS Citarum Hulu selama 6 tahun (2012-2018) hasil simulasi model GenRiver

Tabel 8. Persentase komponen neraca air untuk berbagai skenario perubahan lahan dan iklim tahun 2028 di DAS Citarum Hulu.

\section{Daftar Gambar}

Gambar 1. Peta DAS Citarum Hulu.

Gambar 2. Inti model GenRiver yang merupakan gabungan dari neraca air di tingkat sub-DAS menjadi tingkat DAS .

Gambar 3. Tahapan pemodelan hidrologi dengan menggunakan Model GenRiver. 6

Gambar 4. Kombinasi skenario perubahan tutupan lahan dan iklim...............................................10

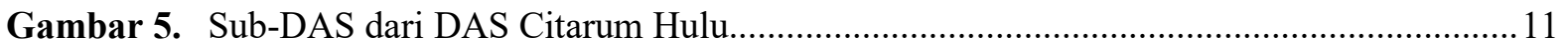

Gambar 6. Sebaran stasiun curah hujan dan hidrologi yang ada di DAS Citarum Hulu ....................13

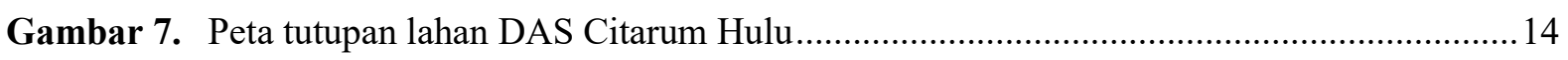

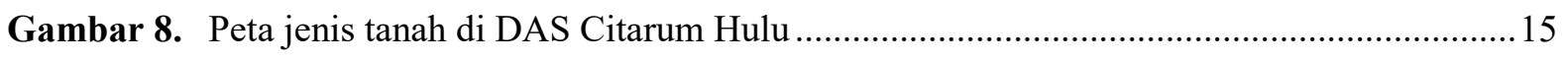

Gambar 9. Hasil analisis kumulatif curah hujan dan debit tahun 2012-2017 .................................. 16

Gambar 10. Perbandingan hidrograf antara data pengukuran di Stasiun Nanjung dengan hasil simulasi Model GenRiver...

Gambar 11. Hasil perbandingan kumulatif curah hujan dan kumulatif debit antara hasil pengukuran di stasiun Nanjung dan hasil simulasi Model GenRiver. 
Gambar 12. Simulasi neraca air DAS Citarum Hulu tahun tahun 2012-2018 (kiri) dan hubungan antara perubahan curah hujan dengan jumlah aliran (kanan)

Gambar 13. Pengaruh perubahan tutupan lahan dan curah hujan terhadap aliran permukaan, aliran bawah permukaan di DAS Citarum Hulu.

Gambar 14. Hasil simulasi neraca air DAS Citarum hulu tahun 2028 berdasarkan berbagai skenario perubahan tutupan lahan dan iklim

Gambar 15. Tren perubahan komponen neraca air tahun 2019-2028 untuk berbagai skenario perubahan tutupan lahan dan iklim.

Gambar 16. Simulasi dampak perubahan tutupan lahan dan iklim di DAS Citarum Hulu 2019-2028 


\section{Pendahuluan}

Daerah Aliran Sungai (DAS) sebagai daerah tangkapan air berperan dalam mendukung penghidupan yang ada didalamnya. Kerusakan DAS dapat memicu berbagai bencana alam seperti banjir, longsor dan kekeringan. Terdapat banyak faktor yang mempengaruhi kondisi DAS, diantaranya adalah tutupan lahan dan iklim. Guo et al (2008) dalam penelitiannya menyebutkan bahwa perubahan tutupan lahan berpengaruh terhadap total debit tahunan dalam suatu DAS. Oleh karena itu pengelolaan DAS terutama pengelolaan tutupan lahan yang tepat harus dilakukan untuk mempertahankan kondisi DAS serta mengurangi permasalahan yang timbul.

Menurut Peraturan Pemerintah No 37 tahun 2012 tentang Pengelolaan Daerah Aliran Sungai, pengelolaan DAS didefinisikan sebagai upaya manusia dalam mengatur hubungan timbal balik antara sumber daya alam dengan manusia di dalam DAS dan segala aktivitasnya, agar terwujud kelestarian dan keserasian ekosistem serta meningkatnya kemanfaatan sumberdaya alam bagi manusia secara berkelanjutan. Tahap pertama dalam pengelolaan DAS tersebut adalah perencanaan yang terdiri dari inventarisasi, penyusunan rencana pengelolaan DAS dan penetapan rencana pengelolaan DAS. Kegiatan inventarisasi disini dapat berupa penetapan batas DAS dan penilaian DAS untuk pengklasifikasian ketegori sebagai yang dipertahankan dan dipulihkan daya dukungnya ${ }^{1}$.

Dengan luas area $6,617 \mathrm{~km}^{2}$, DAS Citarum menjadi salah satu DAS utama di Jawa dan di Indonesia karena perannya sebagai penyedia air bersih, pasokan energi (listrik di Jawa dan Bali) dan pendukung ketahanan pangan karena sebagai sumber irigasi persawahan (Kurniasih N, 2002 dan BBWS, 2016). Namun demikian kondisi DAS Citarum baik secara kualitas dan kuantitas rentan terhadap permasalahan perubahan tata guna lahan, dann terhadap perubahan iklim. Dalam perencanaan DAS, DAS Citarum dibagi menjadi 3 bagian yaitu berdasarkan topografinya, yaitu: (a) DAS Citarum Hulu yang bermuara di Waduk Saguling, (b) DAS Citarum tengah yang bermuara di Waduk Cirata dan (c) DAS Citarum Hilir yang bermuara di Waduk Jatiluhur. Secara umum fungsi DAS bagian hulu dicirikan sebagai daerah konservasi mempunyai arti penting terutama dari segi perlindungan fungsi tata air, karena itu setiap terjadinya kegiatan di daerah hulu akan menimbulkan dampak di daerah hilir dalam bentuk perubahan fluktuasi debit dan transport sedimen serta material terlarut dalam sistem aliran airnya. Oleh karenanya pengelolaan DAS hulu seringkali menjadi fokus perhatian

\footnotetext{
${ }^{1}$ Peraturan Kementerian Kehutanan No 60 tahun 2014 tentang Kriteria Penetapan Klasifikasi Daerah Aliran Sungai.
} 
Studi ini bertujuan untuk menilai fungsi hidrologis DAS Citarum Hulu (Gambar 1). Salah satu cara untuk menilai kondisi DAS adalah berdasarkan pola debit dan neraca air, dimana hal ini dapat dilakukan dengan bantuan model hidrologi. Model hidrologi merupakan suatu representasi matematik sistem respons DAS sehingga dapat dipakai untuk mensimulasikan kondisi input-output dari DAS. Melalui model hidrologi tersebut dapat diprediksi besarnya perubahan debit air yang terjadi sebagai akibat adanya perubahan dalam DAS di masa yang akan datang. Selain itu keberadaaan model juga dapat menghemat biaya, tenaga dan waktu dalam proses penelitian untuk membantu pengambilan kebijakan yang menunjang rencana pengelolaan DAS.

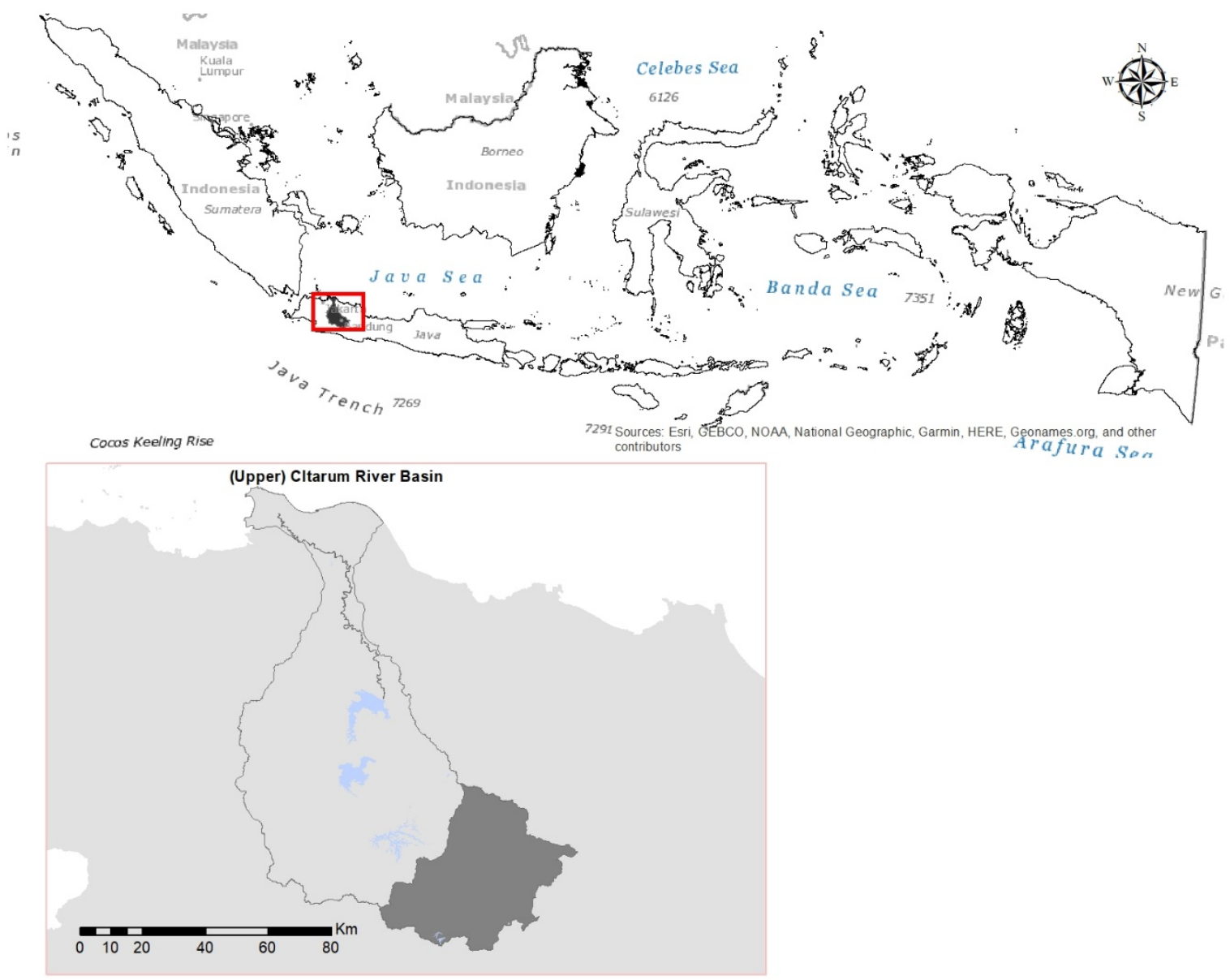

Gambar 1. Peta DAS Citarum Hulu.

Salah satu model hidrologi yang dikembangkan oleh World Agroforestry (ICRAF) adalah model Generic River Flow atau GenRiver (Van Noordwijk et al (2011). GenRiver merupakan suatu model hidrologi yang mensimulasikan dampak perubahan tutupan lahan terhadap kondisi hidrologi. Kondisi hidrologi disini mengacu pada neraca air atau kesetimbangan air yang dilihat dari besarnya evapotranspirasi, aliran permukaan (surface flow), aliran bawah permukaan (subsurface flow) dan aliran dasar (base flow). Selain mengestimasi neraca air di tingkat bentang alam, GenRiver juga dapat untuk melihat tren perubahan komponen neraca air selama periode waktu tertentu dana menjawab pertanyaan seperti ada tidaknya peningkatan aliran permukaan dan penurunan aliran dasar. 
Tahap awal dari penilaian fungsi hidrologis suatu DAS melalui pemodelan adalah evaluasi model apakah layak digunakan untuk penilaian fungsi hidrologi di suatu DAS tertentu.

Tulisan ini merupakan bagian pertama dari dua buah tulisan yang didasarkan pada studi mengenai penilaian fungsi DAS Citarum Hulu menggunakan pendekatan simulasi model. Dalam tulisan pertama ini, akan dipaparkan mengenai kalibrasi model GenRiver dan analisa sensitivitas model terhadap skenario perubahan penggunaan lahan dan perubahan jumlah curah hujan. Tulisan yang kedua akan memeparkan penilaian fungsi hidrologi berdasarkan skenario intervensi penegelolaan lahan pertanian dan implikasinya bagi kebiajakan di daerah DAS Citarum Hulu.

Tulisan in membahas mengenai:

1. Proses kalibrasi model Genriver dengan menganalisa dampak perubahan tutupan lahan dalam periode tahun 2012-2018 terhadap kondisi DAS Citarum hulu

2. Proses analisa sensitivitas dengan mengestimasi dan meproyeksi dampak berbagai skenario perubahan tutupan lahan dan iklim terhadap DAS Citarum pada periode tahun 2019-2028. 


\section{Metodologi}

\section{Model GenRiver}

Model Generic Riverflow (GenRiver) merupakan suatu model sederhana yang mensimulasikan aliran sungai pada suatu DAS atas dasar konversi neraca air dari tingkat plot ke dalam tingkat DAS. Model ini dikembangkan oleh World Agroforestry Centre (ICRAF) untuk membantu menilai secara cepat kondisi suatu DAS dengan bantuan model hidrologi. Model GenRiver telah diaplikasikan pada berbagai kondisi DAS baik di Indonesia maupun di luar Indonesia dengan luasan antara 6-9,800 $\mathrm{km}^{2}$. Penilaian secara cepat didefiniskan sebagai penilaian dengan menggunakan data-data hidroklimat yang tersedia secara publik dari berbagai sumber termasuk lembaga pemerintah dan lembaga penelitian lainnya. Kajian juga dilakukan dengan meminimalisai pengambilan data primer, yang umumnya membutuhkan waktu yang lama. Kegiatan penilaian hidrologis umumnya berlangsung sekitar 6 bulan.

Model GenRiver menggunakan persamaan kesetimbangan (neraca) air yang ditunjukan melalui persamaan 1. Persamaan ini mengasumsikan suatu sistem tata air tertutup pada suatu bentang lahan dimana curah hujan akan dialirkan menjadi debit sungai (Q), evapotranspiration (E) dan air tanah $(\Delta \mathrm{S})$.

$$
\mathrm{P}=\mathrm{Q}+\mathrm{E}+\Delta \mathrm{S}
$$

Konsep inti dari model GenRiver adalah neraca air harian pada tingkat plot yang dihasilkan oleh curah hujan harian dan dipengaruhi oleh perubahan tutupan lahan (Van Noordwijk et al 2011). Keluaran (output) dari neraca air tingkat plot ini adalah hasil air (water yield) yang merupakan penjumlahan dari aliran permukaan (surface flow), aliran bawah permukaan (subsurface flow) dan aliran dasar (base flow). Selanjutnya hasil air dikonversi menjadi debit pada tingkat bentang lahan (watershed) melalui jaringan sungai (jarak ke final outlet). Gambar 2 merupakan ilustrasi konsep dan modul yang berada dalam model GenRiver. Data yang diperlukan untuk dapat mensimulasikan model GenRiver terdiri dari data spasial, iklim dan hidrolog (Tabel 1). 


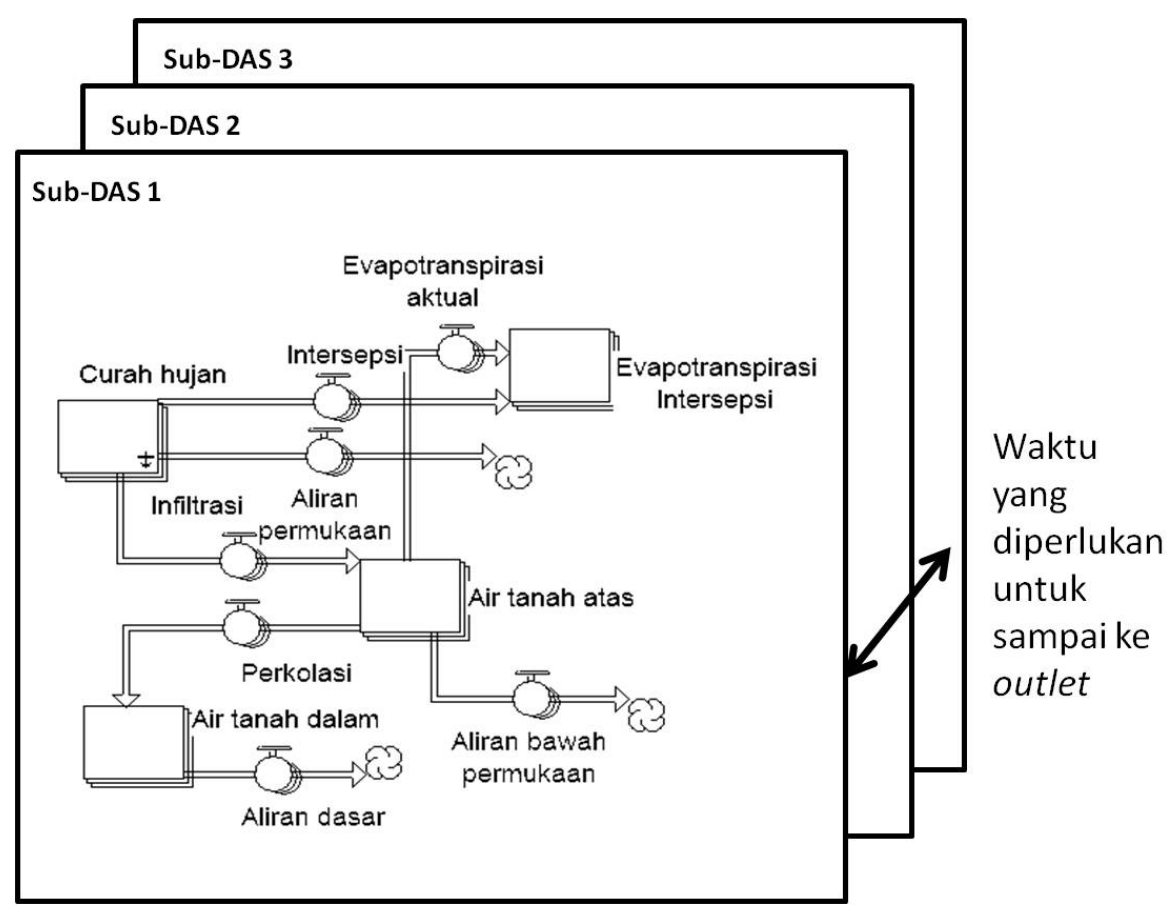

Gambar 2. Inti model GenRiver yang merupakan gabungan dari neraca air di tingkat sub-DAS menjadi tingkat DAS

Tabel 1. Data minimum yang diperlukan untuk mensimulasikan Model GenRiver

\begin{tabular}{cllll}
\hline No & Input & & Periode & Jumlah data minimum \\
\hline \multirow{2}{*}{1} & Iklim & Curah hujan & Harian & 10 tahun data \\
\cline { 3 - 5 } & & Suhu & Harian atau bulanan & 1 tahun data \\
\cline { 3 - 5 } & & Evaporasi dari (Pan evaporation) & Harian atau bulanan & 1 tahun data \\
\hline 2 & Hidrologi & Debit sungai & harian & 10 tahun data \\
\hline 3 & Spasial & Peta tutupan lahan & - & 2 tahun transisi \\
\cline { 3 - 5 } & & Peta tanah & - & - \\
\cline { 3 - 5 } & & Peta DEM $)$ & - & - \\
\cline { 2 - 4 } & Peta sungai & - & \\
\hline
\end{tabular}

\section{Tahapan Pemodelan}

Terdapat tiga tahapan dalam melakukan pemodelan hidrologi menggunakan model GenRiver untuk memenuhi tujuan penelitian ini (Gambar 3).

a. Persiapan input model GenRiver. Tahap ini merupakan persiapan semua input yang diperlukan untuk mensimulasikan model GenRiver termasuk proses pengumpulan dan analisis data. Data yang telah dikumpulkan selanjutnya dianalisis dan disusun sesuai dengan format yang diperlukan oleh model GenRiver. Pengumpulan informasi kondisi DAS dari berbagai pemangku kepentingan (masyarakat, pemerintah, LSM, perusahaan pemanfaat air atau yang ada di area DAS) juga 
diperlukan sebagai informasi dalam menyusun skenario perubahan tutupan lahan. Proses analisis data iklim, hidrologi dan spasial lebih lanjut dapat dilihat pada Khasanah et al (2010).

b. Pemodelan hidrologi menggunakan Model GenRiver. Tahap pemodelan hidrologi dengan model GenRiver dimulai dengan tahap kalibrasi dan validasi model. Kalibrasi merupakan suatu proses penyesuaian beberapa nilai parameter (parameterisasi) dalam model dengan tujuan agar hasil simulasi menyerupai kondisi DAS sebenarnya (Kumarasamy dan Belmont, 2018. Nilai-nilai parameter yang disesuaikan pada umumnya merupakan parameter yang sulit dan memerlukan waktu dan biaya yang cukup besar untuk diukur seperti tingkat infiltrasi, kapasitas maksimum tanah, kekasaran sungai. Validasi merupakan proses perbandingan antara debit hasil simulasi model dengan debit sebenarnya atau pengukuran di lapangan. Setelah tahap kalibrasi dan validasi selesai, tahap selanjutnya adalah mensimulasikan berbagai skenario perubahan tutupan lahan untuk melihat dampaknya terhadap neraca air.

c. Intepretasi model. Tahap ini merupakan tahap akhir, dimana kita membandingkan hasil simulasi berbagai skenario perubahan tutupan lahan dan iklim. Keluaran dari tahap ini dapat menjadi bahan pertimbangan dalam membuat rencana pengelolaan DAS dimasa depan.

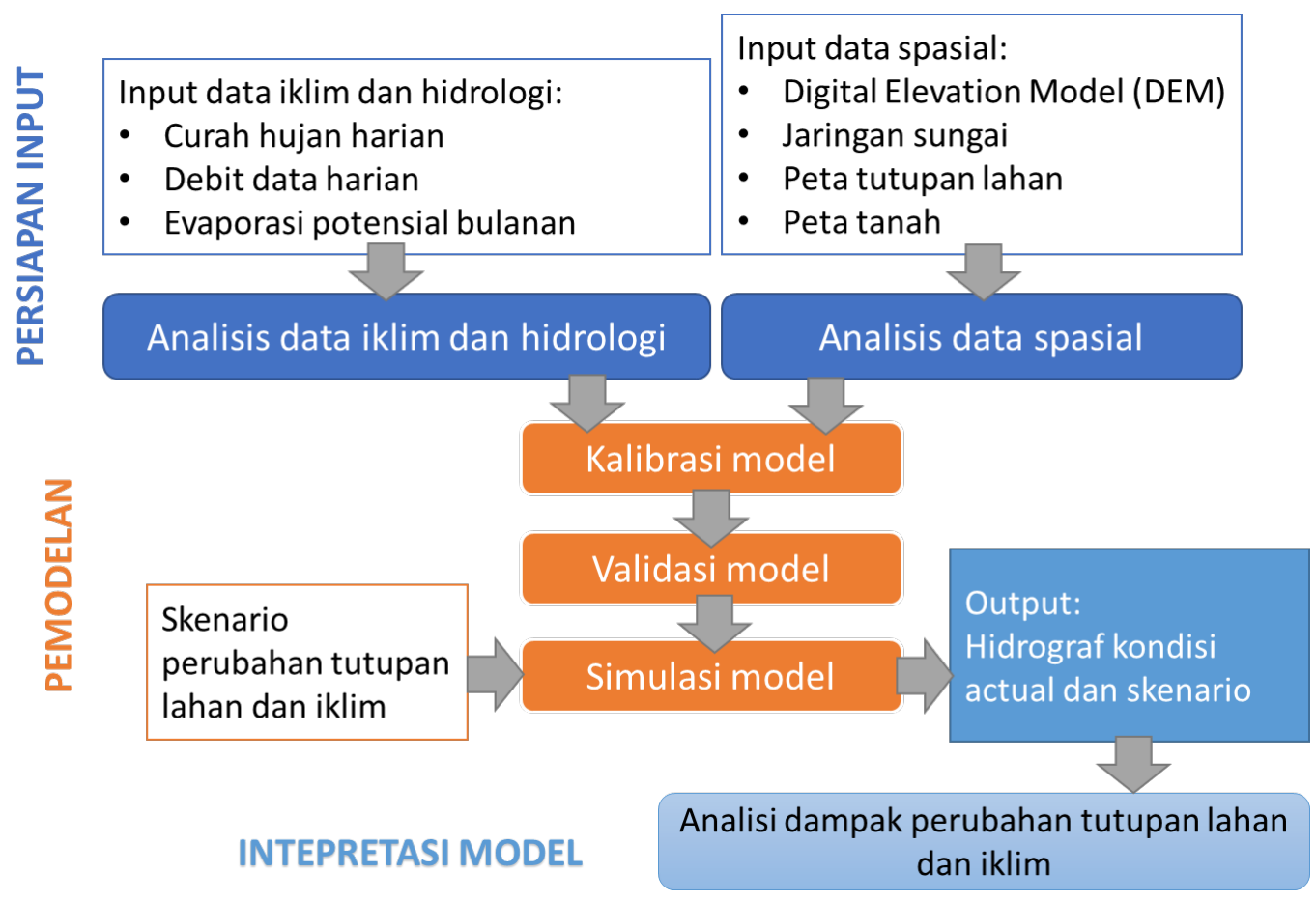

Gambar 3. Tahapan pemodelan hidrologi dengan menggunakan Model GenRiver 


\section{Kalibrasi, Analisa Sensitivitas dan Evaluasi Model}

Kaliabrasi, analisa senistivitas dan evaluasi model adalah kegiatan yang dilakukan pada tahapan awal pemodelan, yang dilakukan untuk menentukan kelayakan model dan parameterisasinya Seperti yang telah disampaikan sebelumnya, kalam mensimulasikan suatu DAS tertentu.

Kalibrasi merupakan suatu proses penentuan nilai parameter yang tidak diukur dari karakteristik DAS dalam suatu model. Kalibrasi umum dilakukan dalam model hidrologi untuk menentukan nilai sekelompok parameter, sehingga hasil simulasi debit oleh model mendekati nilai debit yang sebenarnya (Kumarasamy dan Belmont, 2018). Meskipun proses kalibrasi tidak dapat memperbaiki kesalahan fundamental seperti struktur model dan kualitas data, proses kalibrasi merupakan tahapan penting dan perlu dilakukan untuk meningkatkan keterandalan (reliability) aplikasi model hidrologi.

Analisa sensitivitas dalam pemodelan bertujuan mengukur pengaruh perubahan suatu parameter terhadap faktor lainnya termasuk perubahan hasil simulasi. Dalam pemodelan, khususnya pemodelan hidrologi, kalibrasi dan analisa sensitivitas umum dilakukan secara bersamaan untuk menilai kelayakan aplikasi sebuah model. Dalam studi ini analisa sensitivitas ditujukan untuk melihat kepekaan model dalam mensimulasikan berbagai skenario. Kelayakan akan dinilai dari kemampuan mensimulasikan perubahan neraca air di bentang lahan dalam rentang dua skenario ekstrim.

Evaluasi model sering juga disebut sebagai validasi model merupakan proses penentuan apakah model secara konsep sudah merupakan penyerdehanaan yang mewakili suatu sistem nyata. Terdapat banyak macam metode validasi, dan dalam konteks studi ini, validasi model GenRiver dilakukan dengan membandingkan output simulasi dengan pengamatan/pengukuran lapang. Ada tiga (3) indikator yang digunakan untuk mengukur seberapa dekat debit hasil simulasi dengan debit pengukuran: (i) bias, (ii) koefisien korelasi dan (iii) Nash-Sutcliffe Efficiency. Dalam studi ini, masing-masing indikator dihitung untuk pengamatan harian selama satu tahun untuk setiap tahun periode kalibrasi dan evaluasi 2012-2014.

Bias (\%) mengukur selisih antara total debit sungai harian hasil pengamatan $\left(y_{\text {obs }}\right)$ dengan total debit sungai harian yang dihasilkan simulasi $\left(y_{\text {sim }}\right)$, dihitung dengan menggunakan persamaan 2 dengan menggunakan acuan kinerjaa sesuai Tabel 2.

$$
\text { Bias }=\frac{\sum\left(y_{o b s}-y_{\text {sim }}\right)}{\sum y_{o b s}} \times 100 \%
$$


Tabel 2. Acuan kinerja model dalam memprediksi debit sungai berdasarkan nilai bias.

\begin{tabular}{ll} 
Bias & Kinerja model \\
\hline $\mid$ Bias $\mid<10$ & Sangat baik \\
\hline $10 \leq \mid$ Bias $\mid<15$ & Baik \\
\hline $15 \leq \mid$ Bias $\mid<25$ & Cukup \\
\hline $\mid$ Bias $\mid \geq 25$ & Kurang \\
\hline
\end{tabular}

Koefisien Korelasi (r) mengukur seberapa mirip trend/pola yang dihasilkan total debit sungai harian hasil pengamatan $(x)$ dengan total debit sungai harian yang dihasilkan simulasi $(y)$ dengan jumlah data (n) tertentu, dihitung menggunakan persamaan 3.

$$
\begin{gathered}
S_{x x}=\sum x^{2}-\frac{\left(\sum x\right)^{2}}{n} \\
S_{y y}=\sum y^{2}-\frac{\left(\sum y\right)^{2}}{n} \\
S_{x y}=\sum x y-\frac{\left(\sum x\right)\left(\sum y\right)}{n} \\
R=\frac{S_{x y}}{\sqrt{S_{x x} S_{y y}}}
\end{gathered}
$$

Nilai $r>0.65$ menunjukkan model cukup memuaskan dalam mensimulasikan debit sungai dan sebaliknya nilai $r \leq 0.65$ menunjukkan model kurang memuaskan dalam mensimuasikan debit sungai.

Nash-Sutcliffe Efficiency (NSE) mengukur keragaman sisaan (residual variance) model relative terhadap keragaman data pengamatan (Moriasi DN, et al, 2007). NSE bernilai diantara $-\infty$ (tak terhinga) dan 1, diukur dengan persamaan 4 dengan nilai acuan dalam Tabel 3.

$$
N S E=1-\left[\frac{\sum_{i=1}^{n}\left(Y_{i}^{\text {obs }}-Y_{i}^{\text {sim }}\right)^{2}}{\sum_{i=1}^{n}\left(Y_{i}^{\text {obs }}-Y^{\text {mean }}\right)^{2}}\right]
$$

Dengan $Y_{i}^{\text {obs }}$ sebagai debit sungai harian hasil pengamatan, $Y_{i}^{\text {sim }}$ merupakan debit sungai harian hasil simulasi, $Y^{\text {mean }}$ merupakan rata-rata debit sungai bulanan hasil pengamatan dan $n$ adalah jumlah data yang diamati. 
Tabel 3. Acuan kinerja model dalam memprediksi debit sungai berdasarkan nilai NSE

\begin{tabular}{ll}
\hline Bias & Kinerja model \\
\hline $0.75<\mathrm{NSE} \leq 1.00$ & Sangat baik \\
\hline $0.65<\mathrm{NSE} \leq 0.75$ & Baik \\
\hline $0.50<\mathrm{NSE} \leq 0.65$ & Cukup \\
\hline NSE $\leq 0.5$ & Kurang \\
\hline
\end{tabular}

\section{Skenario Perubahan Tutupan Lahan dan Iklim}

Terdapat lima skenario perubahan tutupan lahan dan tiga skenario perubahan iklim yang disimulasikan untuk sepuluh tahun mendatang $(2019$-2028). Tabel 2 memberikan gambaran skenario perubahan tutupan lahan dan iklim yang akan disimulasikan di DAS Citarum hulu. Skenario hutan primer (NF) dan skenario lahan terbuka (CL) merupakan skenario paling ideal untuk menunjukan kondisi terbaik dan terburuk DAS Citarum Hulu. Skenario BAU dan skenario intensitas curah hujan 25 mm/detik merupakan kondisi saat ini (2018) yang akan digunakan sebagai dasar (baseline) untuk skenario-skenario yang lainnya. Model GenRiver akan disimulasikan berdasarkan kombinasi antara skenario perubahan tutupan lahan dan iklim (Gambar 4). Secara keseluruhan, ada 15 skenario yang dijalankan dalam studi ini.

Tabel 4. Skenario perubahan tutupan lahan dan iklim di DAS Citarum Hulu

\begin{tabular}{|c|c|c|}
\hline Skenario & & Deskripsi \\
\hline \multirow{5}{*}{$\begin{array}{l}\text { Skenario } \\
\text { perubahan } \\
\text { lahan }\end{array}$} & Hutan promer (NF) & $\begin{array}{l}\text { Semua area, kecuali pemukiman diubah menjadi } \\
\text { hutan primer }\end{array}$ \\
\hline & Agroforestri (AF) & $\begin{array}{l}\text { Semua are, kecuali pemukiman dan hutan diubah } \\
\text { menjadi agroforestri }\end{array}$ \\
\hline & Bussiness as Usual (BAU) & $\begin{array}{l}\text { Tidak ada perubahan tutupan lahan (tutupan lahan } \\
\text { tahun } 2028 \text { sama dengan tutupan lahan tahun 2018) }\end{array}$ \\
\hline & Pertanian tanaman semusim (CR) & $\begin{array}{l}\text { Semua area kecuali pemukiman dikonversi menjadi } \\
\text { lahan pertanian semusim }\end{array}$ \\
\hline & Lahan terbuka/terdegradasi $(\mathrm{CL})$ & $\begin{array}{l}\text { Semua area, kecuali permukiman dikonversi menjadi } \\
\text { lahan terbuka/terdegradasi }\end{array}$ \\
\hline \multirow{3}{*}{$\begin{array}{l}\text { Skenario } \\
\text { perubahan } \\
\text { iklim }\end{array}$} & $\mathrm{I}=20 \mathrm{~mm} / \mathrm{detik}$ & Intensitas curah hujan 20 mm/detik \\
\hline & $\mathrm{I}=25 \mathrm{~mm} / \mathrm{detik}$ & $\begin{array}{l}\text { Intensitas curah hujan } 25 \mathrm{~mm} / \mathrm{detik} \text {, kondisi Business } \\
\text { as Usual }\end{array}$ \\
\hline & $\mathrm{I}=30 \mathrm{~mm} / \mathrm{detik}$ & Intensitas curah hujan 30 mm/detik \\
\hline
\end{tabular}




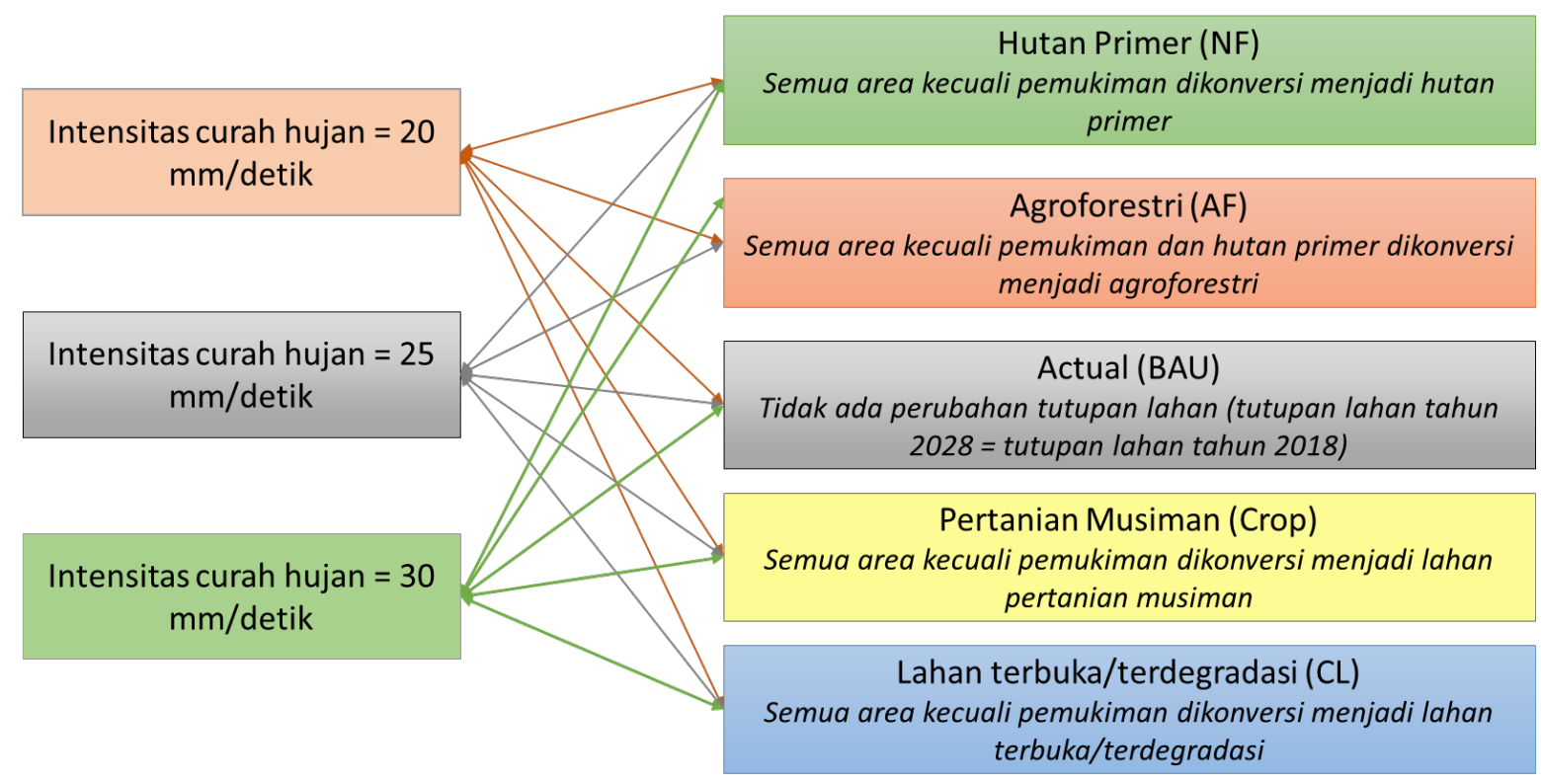

Gambar 4. Kombinasi skenario perubahan tutupan lahan dan iklim 


\section{Karakteristik Lokasi Penelitian}

\section{Sub-DAS dan Jarak Aliran Air}

DAS Citarum Hulu dengan luas tangkapan area sebesar 232,050 Ha (berdasarkan hasil deliniasi) memiliki final outlet di Waduk Saguling. Berdasarkan pengelolaanya, DAS Citarum hulu dapat dibagi menjadi 7 sub-DAS, yaitu: sub-DAS Cirasea, Sub-DAS Cisangkui, Sub-DAS Citarik, Sub-DAS Ciwidey, Sub-DAS Cikapundung, Sub-DAS Ciminyak dan sebagian sub-DAS Cimeta. Dalam penelitian ini, Sub-DAS Cimeta tidak termasuk dalam bagian simulasi karena tidak berada di aliran utama dari sungai Citarum Hulu.

Tabel 3 memperlihatkan hasil analisis spasial untuk jarak perutean (routing distance) dari titik tengah (centroid) masing-masing sub-DAS ke Waduk Saguling seperti ditunjukan oleh Tabel 3. Jarak perutean ini dapat disebut juga sebagai jarak aliran air karena nilainya digunakan untuk memperkirakan waktu tempuh air dari masing-masing sub-DAS hingga mencapai waduk Saguling. Semakin jauh jaraknya maka semakin lama waktu yang diperlukan oleh air untuk mengalir hingga mencapai waduk Saguling.

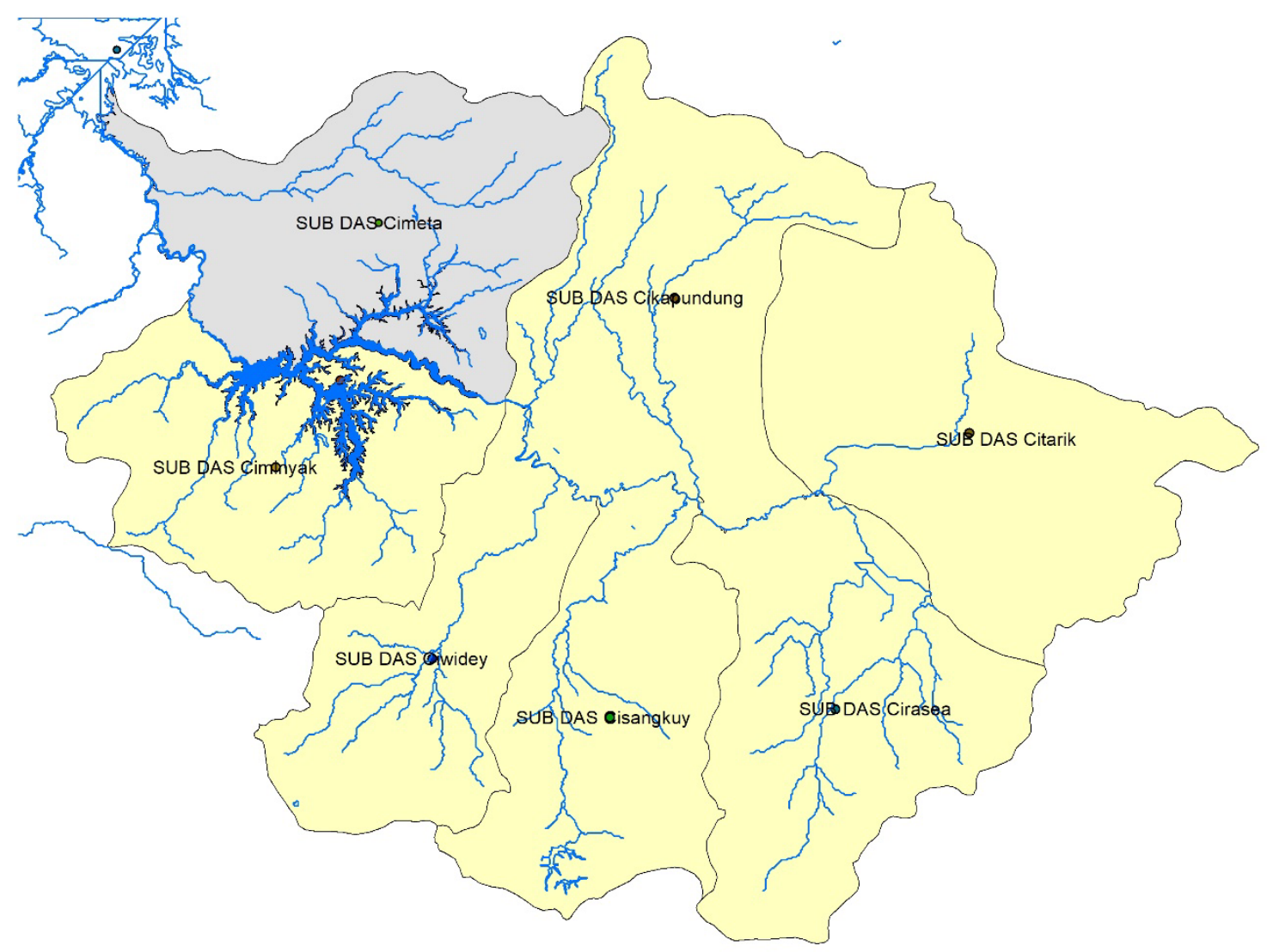

Gambar 5. Sub-DAS dari DAS Citarum Hulu 
Tabel 5. Luas area dan jarak routing masing-masing Sub-DAS di DAS Citarum Hulu

\begin{tabular}{lll}
\hline Sub-DAS & Area $(\mathrm{Ha})$ & Jarak Pusat Sub-DAS Ke Waduk Saguling \\
\hline Cisarea & 37,5 & 88.5 \\
\hline Citarik & 45,9 & 78,0 \\
\hline Cisangkuy & 30,5 & 78.3 \\
\hline Cikapundung & 40,0 & 72.3 \\
\hline Ciwidey & 27,0 & 59.8 \\
\hline Ciminyak & 32,2 & 5,0 \\
\hline Waduk Saguling & 3,3 & 0.0 \\
\hline Total & 216,4 & - \\
\hline
\end{tabular}

\section{Data Iklim dan Hidrologi}

Data curah hujan dan hidrologi yang digunakan dalam penelitian ini merupakan data sekunder yang diperoleh dari Pusat Penelitian dan Pengembangan Sumber Daya Air, Balai Pengelolaan Sumber Daya Air (PSDA) Wilayah Sungai Citarum dan Balai Besar Wilayah Sungai (BBWS) Citarum. Gambar 6 menunjukan sebaran stasiun curah hujan yang ada di DAS Citarum. Terdapat beberapa stasiun yang memiliki data curah hujan yang dimulai sejak tahun 1980, 1990, 2000 dan 2010. Ketersedian data curah hujan dan hidrologi untuk masing-masing stasiun cukup bervariasi bergantung tahun stasiun tersebut mulai beroperasi. Untuk keperluan penelitian ini, data curah hujan dan hidrologi yang digunakan mulai tahun 2012-2018 karena disesuaikan dengan ketersedian peta tutupan lahan. Gambar 6 merupakan sebaran stasiun curah hujan dan hidrologi yang ada di DAS Citarum Hulu. 


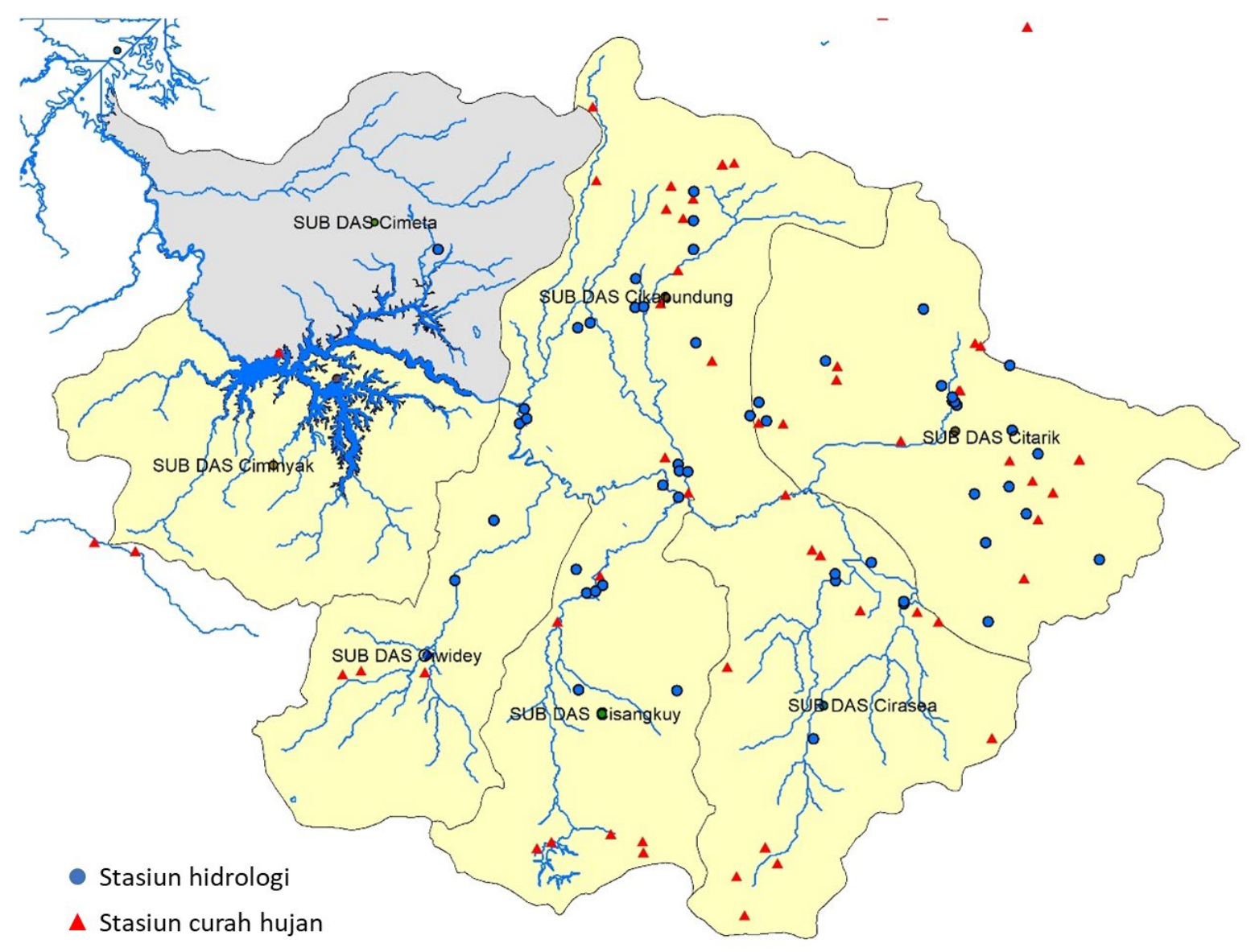

Gambar 6. Sebaran stasiun curah hujan dan hidrologi yang ada di DAS Citarum Hulu

Dari sekian banyak stasiun hidrologi yang ada di DAS Citarum Hulu, Stasiun Nanjung dipilih karena berada di sungai Citarum dan merupakan stasiun terdekat dengan Waduk Saguling, sehingga mendukung hasil kalibrasi model dapat mewakili kondisi yang sebenarnya. Data curah hujan yang digunakan berasal dari tiga stasiun yang berbeda dikarenakan tidak ada stasiun di dekat stasiun Nanjung yang memiliki data curah hujan lengkap (2012-2017). Oleh karena itu diputuskan data curah hujan menggunakan data dari Stasiun Bojong Soang (2016-2017), Stasiun Cicalengka (2012-2014) dan Stasiun Hantap (2015). Ketiga stasiun tersebut merupakan stasiun curah hujan terdekat dengan stasiun Nanjung dan memiliki nilai curah hujan yang mendekati besarnya debit di Stasiun Nanjung.

\section{Tutupan Lahan}

Data tutupan lahan yang digunakan dalam penelitian ini merupakan hasil klasifikasi yang dilakukan oleh World Agroforestry (ICRAF) berdasarkan citra Landsat yang telah dilakukan pengecekan dan verifikasi lapangan. Tutupan lahan di DAS Citarum Hulu dari tahun 2012-2018 didominasi oleh tanaman semusim (23.7\%), pemukiman (16.7\%), sawah (15.5\%) dan agroforestry (12.2\%).

Sedangkan area hutan hanya tersisa di bagian hulu DAS yang merupakan kawasan hutan milik 
negara. Gambar 7 dan Tabel 4 menunjukan perubahan tutupan lahan di DAS Citarum hulu dari tahun 2012-2018. Selama 6 tahun, perubahan terbesar terjadi pada berkurangnya area hutan sekunder kerapatan tinggi ( $4.32 \%$ atau 9,341 ha), berkurangnya area tanaman semusim ( $4.12 \%$ atau $8925 \mathrm{ha})$, bertambahnya area agroforestry campuran ( $4.27 \%$ atau 9,239 ha), pemukiman ( $2.93 \%$ atau 6,344 ha) dan sawah (2.89\% atau 6,258 ha).
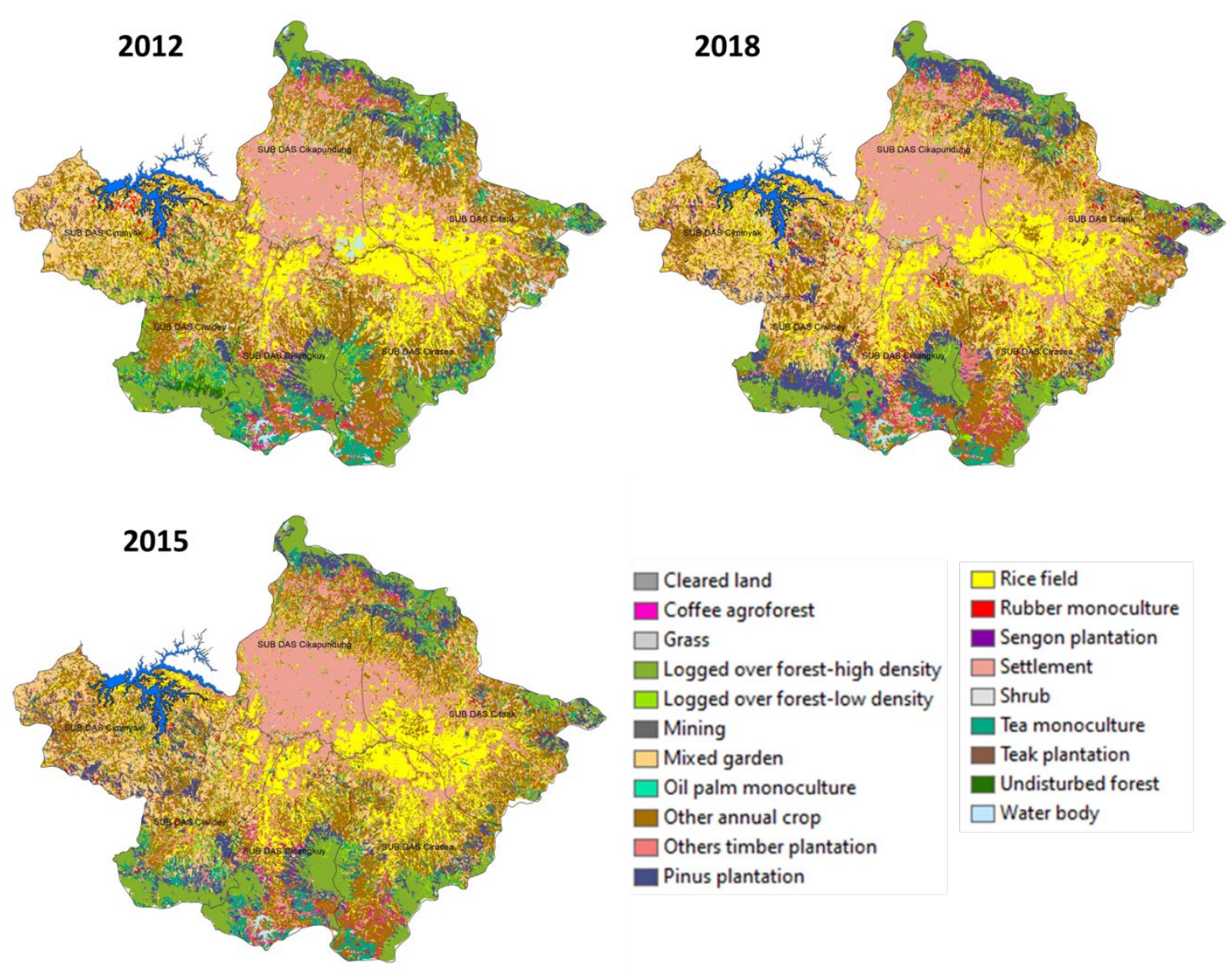

Gambar 7. Peta tutupan lahan DAS Citarum Hulu

Tabel 6. Luas area masing-masing jenis tutupan lahan di DAS Citarum Hulu

\begin{tabular}{lrrrrrr}
\hline \multirow{2}{*}{ Jenis Tutupan Lahan } & \multicolumn{3}{c}{$\mathbf{2 0 1 2}$} & $\mathbf{2 0 1 5}$ & $\mathbf{2 0 1 8}$ \\
\cline { 2 - 7 } & $\mathbf{H a}$ & $\mathbf{\%}$ & $\mathrm{Ha}$ & $\mathbf{\%}$ & Ha & $\mathbf{\%}$ \\
\hline Hutan Primer & 1,380 & 0.64 & 25 & 0.01 & 25 & 0.01 \\
\hline Hutan Sekunder Kerapatan Tinggi & 27,291 & 12.61 & 22,230 & 10.27 & 17,945 & 8.29 \\
\hline Hutan Sekunder Kerapatan Rendah & 5,248 & 2.42 & 4,798 & 2.22 & 2,224 & 1.03 \\
\hline Agroforestri Campur & 22,037 & 10.18 & 25,806 & 11.93 & 31,273 & 14.45 \\
\hline Agroforestri Kopi & 1,888 & 0.87 & 2,910 & 1.34 & 2,591 & 1.20 \\
\hline Perkebunan Karet & 679 & 0.31 & 2,333 & 1.08 & 2,272 & 1.05 \\
\hline Perkebunan Kelapa Sawit & 41 & 0.02 & 41 & 0.02 & 41 & 0.02 \\
\hline Perkebunan Jati & 559 & 0.26 & 2,458 & 1.14 & 1,869 & 0.86 \\
\hline Perkebunan Sengon & 910 & 0.42 & 984 & 0.45 & 1,613 & 0.75 \\
\hline
\end{tabular}




\begin{tabular}{lrrrrrr}
\hline \multirow{2}{*}{ Jenis Tutupan Lahan } & \multicolumn{3}{c}{$\mathbf{2 0 1 2}$} & $\mathbf{2 0 1 5}$ & $\mathbf{2 0 1 8}$ \\
\cline { 2 - 7 } & $\mathbf{H a}$ & $\mathbf{\%}$ & $\mathrm{Ha}$ & $\mathbf{\%}$ & $\mathrm{Ha}$ & $\mathbf{\%}$ \\
\hline Perkebunan Pinus & 10,458 & 4.83 & 15,032 & 6.95 & 16,233 & 7.50 \\
\hline Pekebunan Lainnya & 690 & 0.32 & 1,796 & 0.83 & 2,944 & 1.36 \\
\hline Perkebunan Teh & 9,620 & 4.45 & 10,049 & 4.64 & 6,412 & 2.96 \\
\hline Sawah & 30,292 & 14.00 & 33,984 & 15.70 & 36,544 & 16.89 \\
\hline Tanaman Semusim & 55,543 & 25.67 & 51,736 & 23.91 & 46,609 & 21.54 \\
\hline Pemukiman & 33,018 & 15.26 & 35,778 & 16.53 & 39,356 & 18.19 \\
\hline Lahan Terbuka & 11,820 & 5.46 & 2,225 & 1.03 & 4,054 & 1.87 \\
\hline Tambang & 30 & 0.01 & 26 & 0.01 & 172 & 0.08 \\
\hline Tubuh Air & 4,900 & 2.26 & 4,192 & 1.94 & 4,190 & 1.94 \\
\hline Total & 216,404 & 100 & 216,405 & 100 & 216,366 & 100 \\
\hline
\end{tabular}

\section{Jenis Tanah}

Berdasarkan peta tanah (sumber: Repprot), jenis tanah di DAS di Citarum Hulu didominasi oleh jenis tanah Inseptisols (80\%) sedangkan sisanya berupa jenis tanah Ultisols (20\%) (Gambar 8).

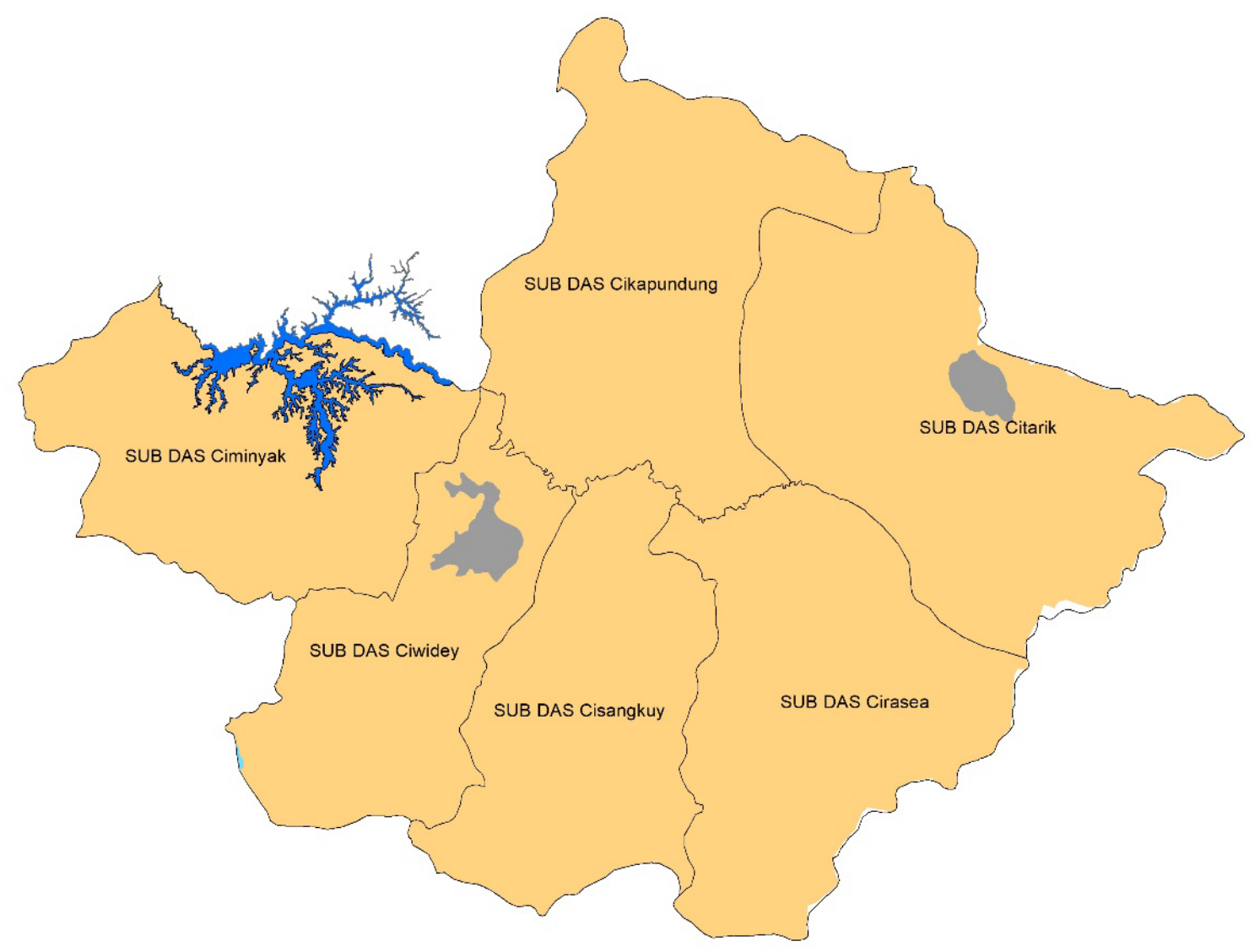

Gambar 8. Peta jenis tanah di DAS Citarum Hulu 


\section{Uji kesesuaian data iklim dan hidrologi}

Data-data yang akan digunakan ini, diuji terlebih dahulu kesesuaiannya. Data yang sesuai akan memiliki kesamaan pola, i.e. curah hujan tinggi akan menyebabkan peningkatan atau setidaknya kestabilan debit air. Jika terjadi perbedaan pola, i.e. curah hujan tinggi tetapi penurunan debit sugai atau tidak ada debit sungai sama sekali, maka perlu dikaji ulang mengapa ini bisa terjadi dan juga dkaji ulang kelayakan data curah hujan dan debit sungai untuk digunakan dalam model GenRiver.

Data tahun 2017 memiliki nilai evaporasi yang sangat kecil (kurang dari $500 \mathrm{~mm} / \mathrm{tahun}$ ) dan tahun 2015 memiliki pola dimana terjadi kenaikan debit sungai Citarum tanpa adanya kenaikan curah hujan (Gambar 9). Hasil analisis ini akan digunakan sebagai masukan untuk menjelaskan hasil kalibrasi dan validasi model.
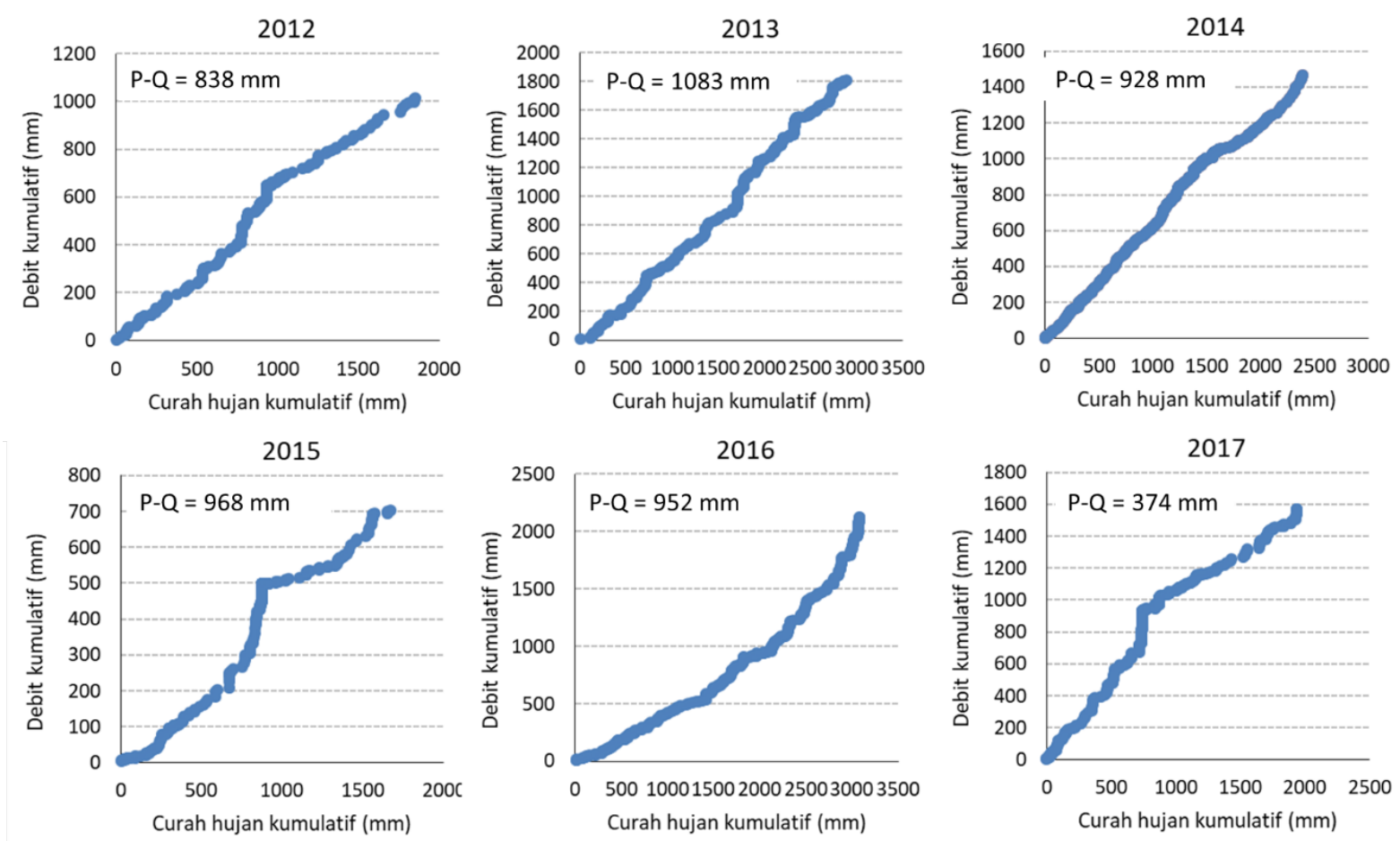

Keterangan: $\mathrm{P}=$ curah hujan, $\mathrm{Q}=\operatorname{debit}, \mathrm{P}-\mathrm{Q}=$ Evaporasi

Gambar 9. Hasil analisis kumulatif curah hujan dan debit tahun 2012-2017 


\section{Hasil dan Pembahasan}

\section{Kalibrasi dan Evaluasii Model GenRiver}

Kalibrasi model GenRiver dengan berdasarkan data curah hujan di Stasiun Bojong Soang (20162017), Stasiun Cicalengka (2012-2014) dan Stasiun Hantap (2015), serta data debit sungai di stasiun Nanjung (2012-2017) memperoleh hasil parameterisasi Model GenRiver seperti yang ditunjukan pada Tabel 5. Hasil kalibrasi dan evaluasi menunjukan bahwa dari 6 tahun simulasi, terdapat hasil simulasi yang memiliki nilai NSE kurang dari 0.5, yaitu tahun 2015 dan 2016 (Tabel 6). Hal ini sesuai dengan hasil yang diperoleh pada saat melakukan uji kesesuaian data curah hujan dan debit sungai (Gambar 9) yang menunjukkan adanya ketidakcocokan antara pola debit sungai dengan curah hujan. Lebih lanjut, Gambar 10 dan 11 menunjukan secara deskriptif perbandingan antara hasil pengukuran debit sungai dengan hasil simulasi debit dengan model GenRiver.

Berdasarkan hasil evaluasi kinerja model dalam mensimulasikan debit sungai Citarum tahun 2012 2018 dapat disimpulkan bahwa model cukup memadai dalam mensimulasikan neraca air di DAS Citarum Hulu. Ketidakmampuan model dalam melakukan simulasi disebabkan karena rendahnya kualitas data yang ada pada tahun 2014-1018. Dengan demikian, model hasil kalibrasi dapat digunakan untuk mensimulasikan skenario perubahan dan penggunaan lahan di DAS Citarum Hulu.

Tabel 7. Hasil parameterisasi Model GenRiver untuk DAS Citarum Hulu

\begin{tabular}{lll}
\hline Nama Parameter & Keterangan & Nilai \\
\hline RainInterceptDripRt & Tingkat intersepsi tetesan curah hujan & 10 \\
\hline RainMaxIntDripDur & Durasi intersepsi tetesan curah hujan & 0.5 \\
\hline InterceptEffectontrans & Pengaruh intersepsi curah hujan pada transpirasi & 0.4 \\
\hline RainIntensMean & Rata-rata intensitas curah hujan & 25 \\
\hline RainIntensCoefVar & Koefisien variasi intensitas curah hujan & 0.3 \\
\hline MaxInfRate & Kapasitas maksimum infiltrasi per hari & 900 \\
\hline MaxInfSubsoil & Kapasitas maksimum infiltrasi ke sub-tanah per hari & 200 \\
\hline PerFracMultiplier & Fraksi pelepasan air tanah per hari & 0.15 \\
\hline MaxDynGrWatStore & Kapasitas maksimum penyimpanan air tanah & 100 \\
\hline GWReleaseFracConst & Fraksi pelepasan aliran dasar & 0.05 \\
\hline Tortuosity & Faktor bentuk DAS & 0.7 \\
\hline Dispersal Factor & Kerapatan aliran & 0.5 \\
\hline River Velocity & Kecepatan aliran & 0.6 \\
\hline
\end{tabular}


Tabel 8. Hasil Kalibrasi dan validasi Model GenRiver untuk DAS Citarum Hulu

\begin{tabular}{ccccccc} 
Year & $\mathbf{n}$ & Biased (\%) & NSE & $\mathbf{r}$ & Biased (\%) & NSE \\
\hline 2012 & 12 & 9.14 & 0.84 & 0.94 & Very good & very good \\
\hline 2013 & 12 & 17.52 & 0.56 & 0.91 & satisfactory & satisfactory \\
\hline 2014 & 12 & -11.46 & 0.82 & 0.96 & good & very good \\
\hline 2015 & 12 & 51.59 & -0.34 & 0.67 & unsatisfactory & unsatisfactory \\
\hline 2016 & 12 & 0.42 & -0.65 & 0.25 & Very good & unsatisfactory \\
\hline 2017 & 12 & -21.40 & 0.62 & 0.81 & satisfactory & satisfactory
\end{tabular}
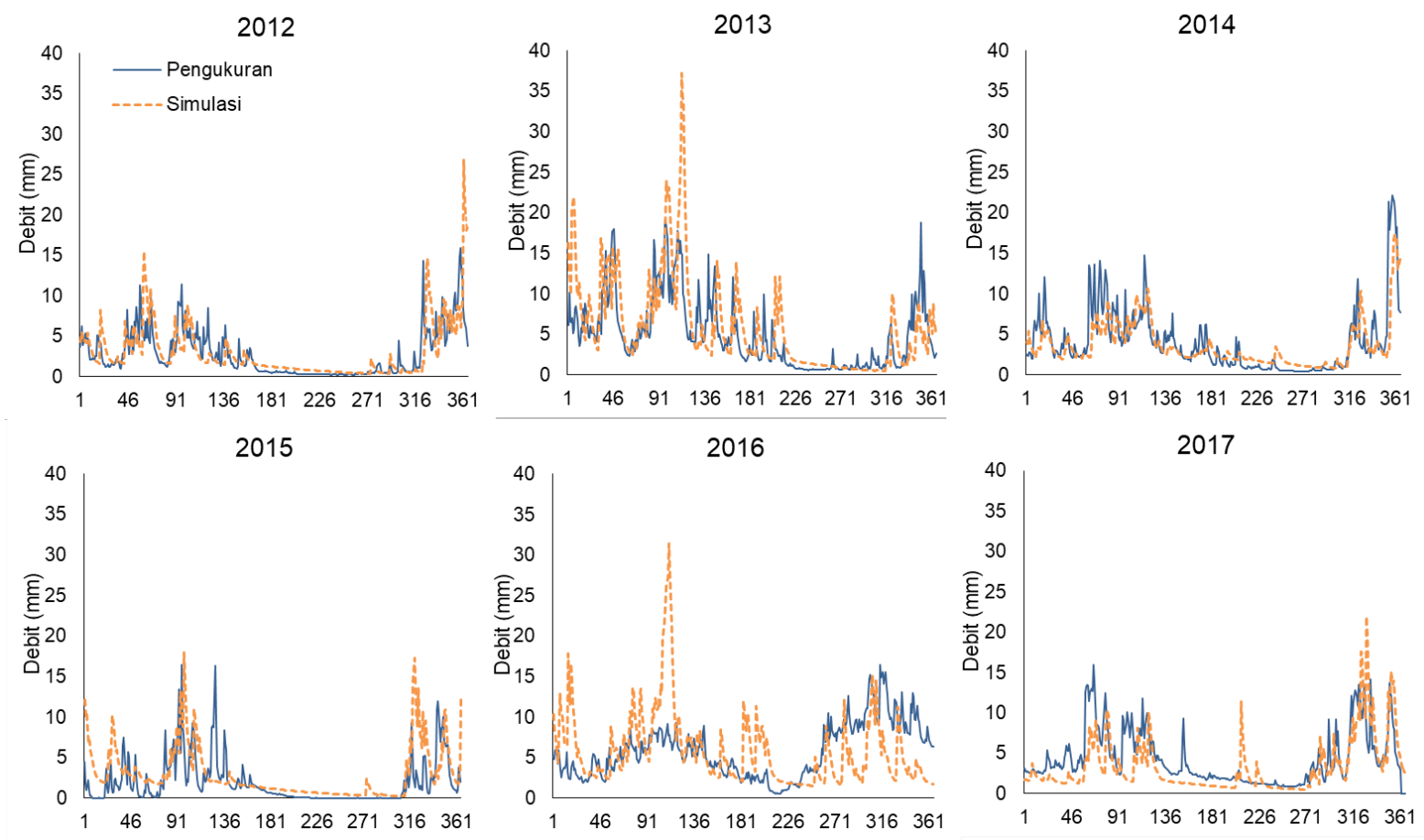

Gambar 10. Perbandingan hidrograf antara data pengukuran di Stasiun Nanjung dengan hasil simulasi Model GenRiver 

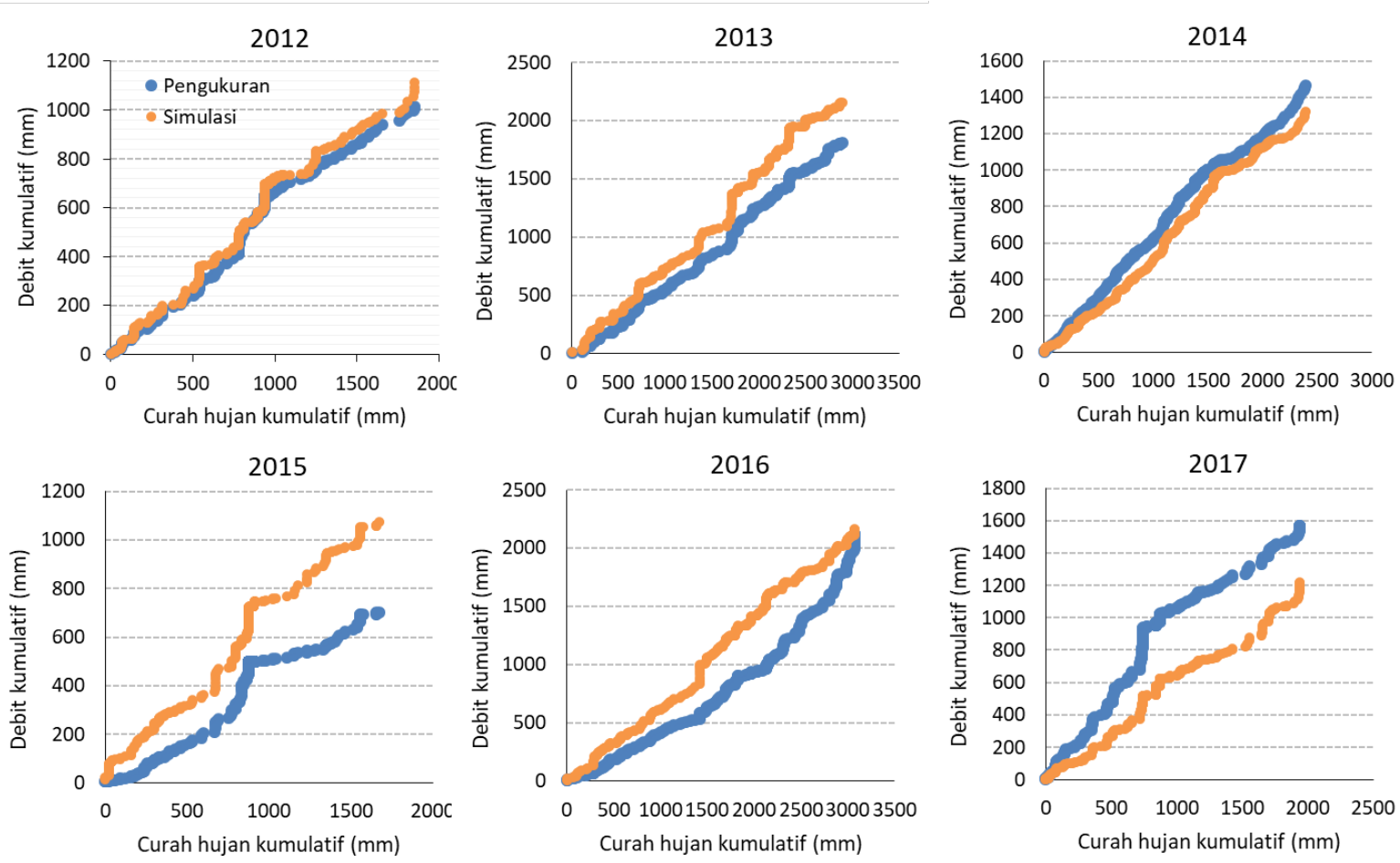

Gambar 11. Hasil perbandingan kumulatif curah hujan dan kumulatif debit antara hasil pengukuran di stasiun Nanjung dan hasil simulasi Model GenRiver

\section{Simulasi Dampak Perubahan Tutupan Lahan terhadap Kondisi DAS Citarum Hulu Tahun 2012-2018}

Berdasarkan hasil simulasi model yang telah dikalibrasi, neraca air DAS Citarum hulu selama 6 tahun (2012-2018) memiliki rata-rata tahunan evapotranspirasi sebesar $787 \mathrm{~mm}$ atau $35 \%$ dari total neraca air bentang lahan dalam periode tersebut, aliran permukaan sebesar $824 \mathrm{~mm} \mathrm{(37 \% ),} \mathrm{aliran} \mathrm{bawah}$ permukaan sebesar $154 \mathrm{~mm}$ (7\%) dan aliran dasar sebesar $415 \mathrm{~mm}$ (20\%) dengan total curah hujan bervariasi antara 1670-3076 mm dengan rata-rata $2230 \mathrm{~mm}$ (Tabel 7). Secara umum, sulit untuk memvalidasi hasil neraca air ini, khususnya komponen debit sungai karena hampir tidak adanya data di tingkat bentang lahan sebagai pembanding karena sulitnya pengukuran. Yang dapat dilakukan adalah dengan membadingkan terhdaap teori/konsep yang ada mengenai neraca air di iklim tropis basah, seperti nilai evapotranspirasi tdak pernah melebihi total curah hujan (Peters T, 2014). 
Tabel 9. Kondisi neraca air DAS Citarum Hulu selama 6 tahun (2012-2018) hasil simulasi model GenRiver

\begin{tabular}{lllllll}
\hline \multirow{2}{*}{ Komponen neraca air } & \multicolumn{2}{l}{ Terendah } & \multicolumn{2}{c}{ Rata-rata } & \multicolumn{2}{c}{ Tertinggi } \\
\cline { 2 - 7 } & $\mathrm{mm}$ & $\%$ & $\mathrm{~mm}$ & $\%$ & $\mathrm{~mm}$ & $\%$ \\
\hline Curah hujan & 1670 & & 2230 & & 3076 & 34 \\
\hline Evapotranspirasi & 645 & 39 & 787 & 35 & 1055 & 68 \\
\hline Debit sungai & 989 & 59 & 1424 & 64 & 2101 & 39 \\
\hline Aliran permukaan & 548 & 33 & 824 & 37 & 1204 & 10 \\
\hline Aliran bawah permukaan & 28 & 2 & 154 & 7 & 315 & 21 \\
\hline Aliran dasar & 355 & 21 & 451 & 20 & 644 & \\
\hline
\end{tabular}

Gambar 12A menunjukan variasi neraca air berdasarkan data pengamatan curah hujan dan tutupan lahan yang diperoleh dari pemetaan. Pada awal simulasi, tahun 2012, tutupan lahan terdiri atas $39.7 \%$ tanaman semusim termasuk sawah, 20.7\% pemukiman dan lahan terbuka, 16.9\% sistem pepohonan seperti perkebunan tanaman keras dan agroforestry, $15 \%$ hutan sekunder dan kurang dari $0.7 \%$ hutan primer (Gambar 7 dan Tabel 4). Selama periode 2012-2018 terjadi penurunan hutan primer sebesar hampir $100 \%$ dan hutan sekunder $38 \%$, setara dengan sekitar 1350 ha dan 12,370 ha. Tanaman semusim mengalami penngkatan sebesar 53\% setara dengan 19,320 ha. Gambar 12B merupakan grafik hubungan antara total curah hujan dengan aliran permukaan, aliran bawah permukaan dan aliran dasar. Semakin tinggi curah hujan tahunan maka aliran permukaan, aliran bawah permukaan dan aliran dasar akan meningkat. Pada DAS Citarum Hulu, setiap kenaikan $100 \mathrm{~mm}$ curah hujan akan meningkatkan aliran permukaan sebesar $40 \mathrm{~mm}$, aliran bawah permukaan $19 \mathrm{~mm}$ dan aliran dasar 20 $\mathrm{mm}$.
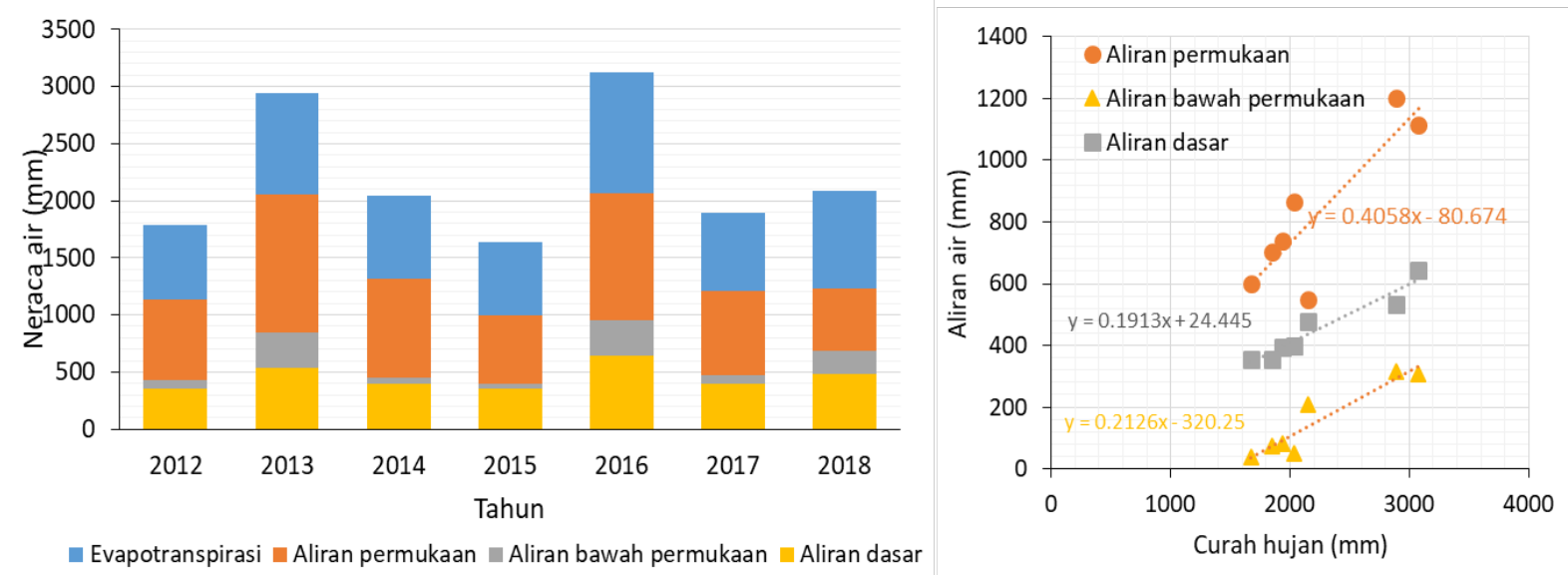

Gambar 12. Simulasi neraca air DAS Citarum Hulu tahun tahun 2012-2018 (kiri) dan hubungan antara perubahan curah hujan dengan jumlah aliran (kanan)

Lebih lanjut, selama 6 tahun simulasi (2012-2016) dengan curah hujan yang sama $(\mathrm{CH}=1851 \mathrm{~mm}$ dan CH $3076 \mathrm{~mm}$ ), terlihat bahwa perubahan tutupan lahan terjadi kenaikan aliran permukaan, aliran bawah permukaan dan aliran dasar sekitar $2 \mathrm{~mm}$ per tahun (Gambar 13). Ini menunjukkan bahwa perubahan lahan yang terjadi tidak memberikan perubahan yang signifikan terhadap perubahan neraca 
air di DAS Citarum Hulu, karena proporsi luas area hutan yang stabil, kurang dari 1\%, dan luas tanaman semusim yang stabil di 20-25\% selama tahun 2012-2016.
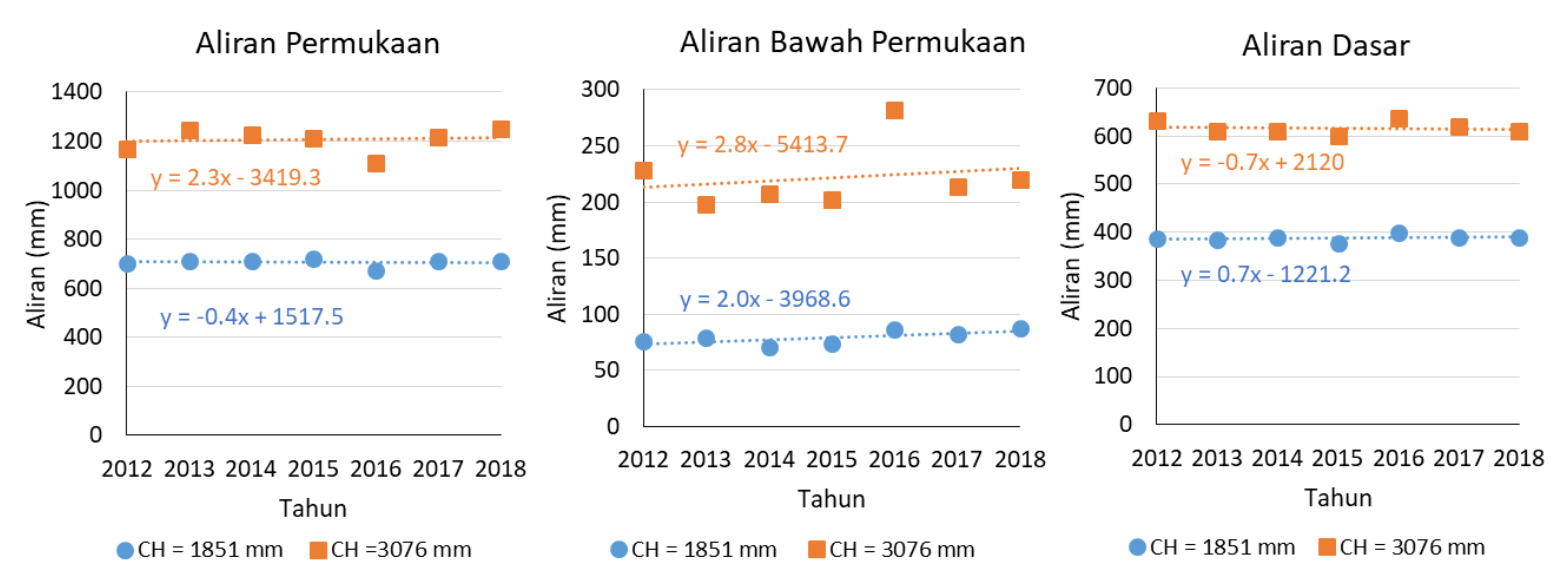

Gambar 13. Pengaruh perubahan tutupan lahan dan curah hujan terhadap aliran permukaan, aliran bawah permukaan di DAS Citarum Hulu

\section{Simulasi Skenario Perubahan Tutupan Lahan dan Iklim Terhadap Kondisi DAS Citarum Hulu di Masa Depan (2019-2028)}

Simulasi skenario perubahan tutupan dan iklim untuk melihat variasi kondisi hidrologi di DAS Citarum hulu. Terdapat lima skernario perubahan tutupan lahan dan 3 skenario perubahan iklim yang disimulasikan untuk tahun 2019 - 2028 (Tabel 4). Kelima skenario perubahan lahan yaitu (1) peningkatan hutan primer (NF), (2) peningkatan agroforestri (AF), (3) Business as usual, dimana tutupan lahan tahun $2018=2028$ (BAU), (4) Peningkatan pertanian tanaman semusim (Crop) dan (5) peningkatan lahan terbuka/terdegradasi (CL). Ketiga skenario perubahan iklim terdiri dari (i) penurunan intensitas curah hujan - ( $\mathbf{I}=\mathbf{2 0} \mathbf{~ m m} / \mathbf{d e t i k})$, (2) intensitas curah hujan sama dengan kondisi saat ini - (I = $\mathbf{2 5} \mathbf{~ m m} /$ detik), (iii) peningkatan intensitas curah hujan - (I = $30 \mathbf{~ m m} /$ detik $)$.

Secara umum berdasarkan Tabel 8 dan Gambar 14 memperlihatkan perbandingan komponen neraca air pada tahun 2028 dari berbagai skenario tutupan lahan dan perubahan iklim. Hasil simulasi memperlihatkan bahwa peningkatan tanaman pepohonan atau vegetasi berkayu (NF dan AF) akan menurunkan tingkat aliran permukaan dan meningkatkan aliran bawah permukaan serta aliran dasar. Sebaliknya pengurangan vegetasi berkayu (Crop dan CL) akan meningkatkan aliran permukaan dan menurunkan aliran bawah permukaan serta aliran dasar. Selain itu Gambar 14 juga memperlihatkan bahwa kenaikan intensitas curah hujan juga menyebabkan kenaikan aliran permukaan dan penurunan bawah permukaan dan aliran dasar. Lebih lanjut aliran permukaan merupakan komponen neraca air yang paling rentan terhadap perubahan tutupan lahan dan iklim, sedangkan aliran dasar menjadi komponen yang paling tidak rentan terhadap perubahan tersebut (Gambar 14). 
Tabel 10. Persentase komponen neraca air untuk berbagai skenario perubahan lahan dan iklim tahun 2028 di DAS Citarum Hulu

\begin{tabular}{llccccc}
\hline \multirow{2}{*}{ Skenario Perubahan iklim } & \multirow{5}{*}{ Komponen neraca air (\%) } & \multicolumn{5}{c}{ Skenario perubahan lahan } \\
\cline { 2 - 6 } I=20 mm/detik & Aliran dasar & NF & AF & BAU & Crop & CL \\
\cline { 2 - 6 } & Aliran bawah permukaan & 23.6 & 23.5 & 19.4 & 20.9 & 21.1 \\
\cline { 2 - 6 } & Aliran permukaan & 13.2 & 26.4 & 46.1 & 41.7 & 52.0 \\
\cline { 2 - 6 } & Evapotranspirasi & 38.8 & 34.3 & 31.3 & 32.1 & 22.6 \\
\hline I=25 mm/detik & Aliran dasar & 23.7 & 22.3 & 20.7 & 19.1 & 19.4 \\
\cline { 2 - 6 } & Aliran bawah permukaan & 19.9 & 10.7 & 5.5 & 3.0 & 2.2 \\
\cline { 2 - 6 } & Aliran permukaan & 18.1 & 33.6 & 41.4 & 47.9 & 57.2 \\
\cline { 2 - 6 } & Evapotranspirasi & 38.2 & 33.5 & 32.6 & 30.2 & 21.5 \\
\hline \multirow{2}{*}{ I=30 mm/detik } & Aliran dasar & 22.9 & 21.2 & 19.4 & 17.7 & 17.9 \\
\cline { 2 - 6 } & Aliran bawah permukaan & 17.0 & 7.5 & 3.5 & 2.1 & 1.3 \\
\cline { 2 - 6 } & Aliran permukaan & 22.4 & 38.8 & 46.1 & 52.0 & 60.8 \\
\cline { 2 - 6 } & Evapotranspirasi & 37.6 & 32.7 & 31.3 & 28.6 & 20.5 \\
\hline
\end{tabular}
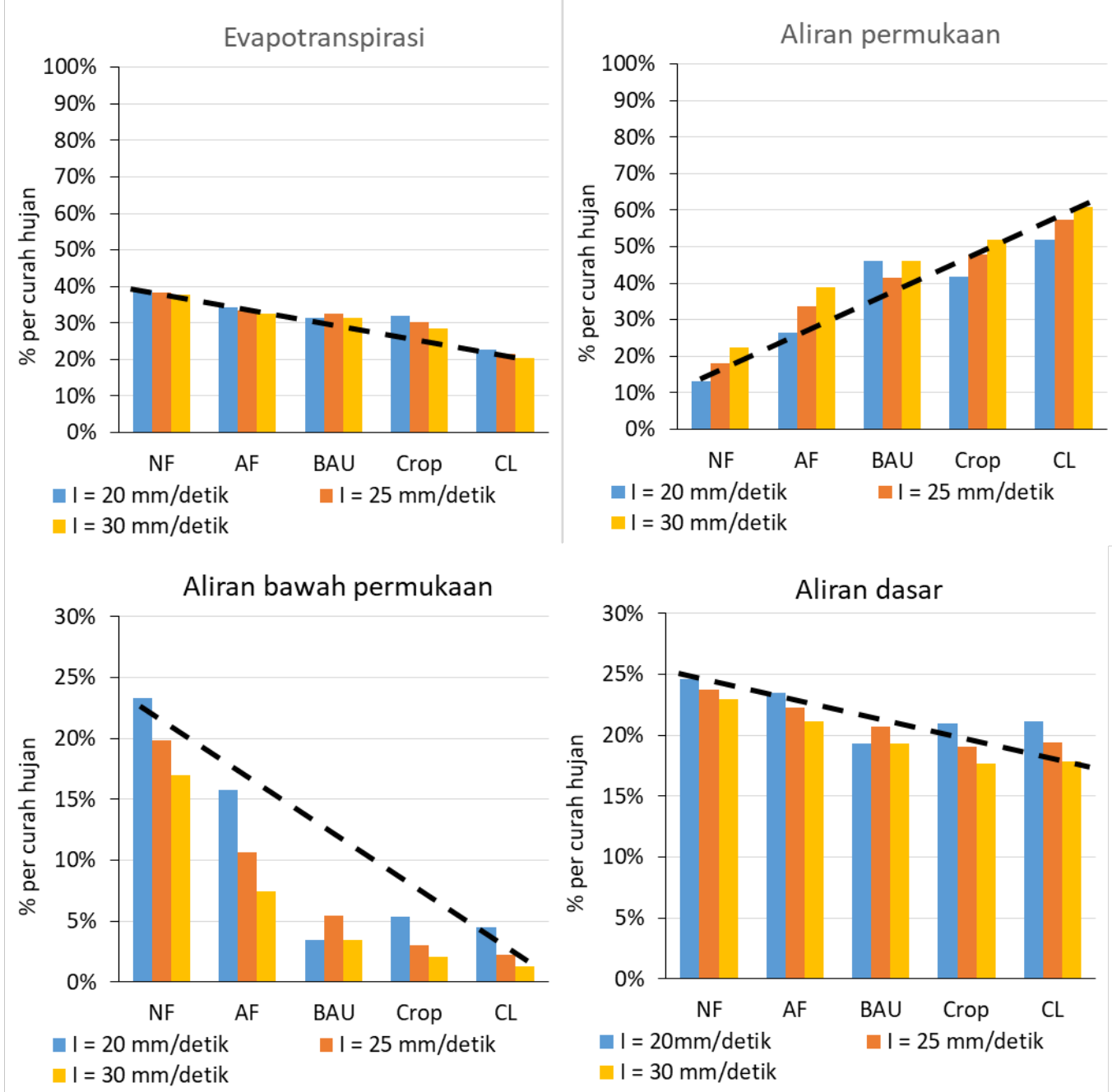

Gambar 14. Hasil simulasi neraca air DAS Citarum hulu tahun 2028 berdasarkan berbagai skenario perubahan tutupan lahan dan iklim 
Jika dibandingkan dengan skenario BAU, skenario NF dan AF memberikan dampak perubahan yang signifikan terhadap perubahan aliran permukaan dan aliran bawah permukaan (Gambar 15).

Sebaliknya skenario pembukaan lahan secara besar-besaran (CL) akan menyebabkan evapotranspirasi menurun secara drastis dan berubah menjadi aliran permukaan, yang akan meningkatkan potensi terjadinya banjir bandang.
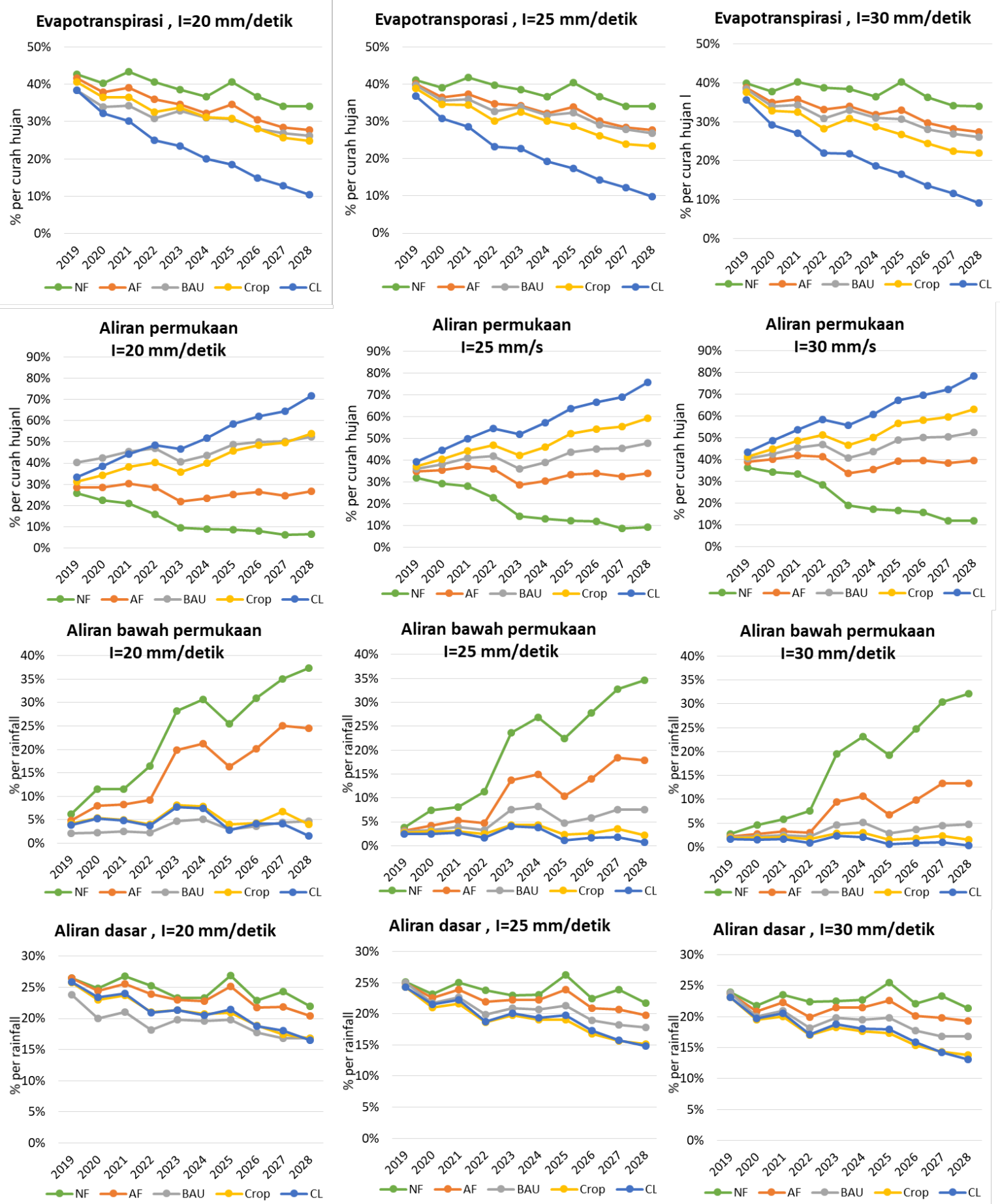

Gambar 15. Tren perubahan komponen neraca air tahun 2019-2028 untuk berbagai skenario perubahan tutupan lahan dan iklim. 
Gambar 16 memberikan analisis lebih lanjut perubahan aliran permukan pada skenario NF dan skenario CL. Analisis lebih lanjut menunjukan bahwa konversi $82 \%$ (174,723 ha) lahan di hulu DAS Citarum menjadi area hutan alami akan menurunkan aliran permukaan sebesar $22 \%$ terhadap total curah hujan. Sebaliknya pembukaan lahan dengan luas yang sama menjadi lahan terbuka akan menyebabkan 70\% hujan menjadi aliran permukaan pada akhir simulasi (tahun 2028). Secara umum dalam skenario ini $5 \mathrm{~mm} /$ detik dari curah hujan akan menyebabkan kenaikan aliran permukaan sekitar $5 \%$ dari curah hujan.

Skenario NF dan CL merupakan kondisi ekstrim yang dalam kenyataannya akan sulit terjadi. Namun hasil kondisi ekstrim ini dapat memberikan gambaran rentang pemulihan dan degradasi DAS Citarum Hulu yang mungkin terjadi. Skema intervensi di tingkat plot melalui konservasi tanah dan lahan maupun intervensi di tingkat bentang alam melalui kebijakan perencanaan wilayah akan menghasilkan neraca air di tingkat bentang alam yang berada di rentang skenarion NF dan CL.
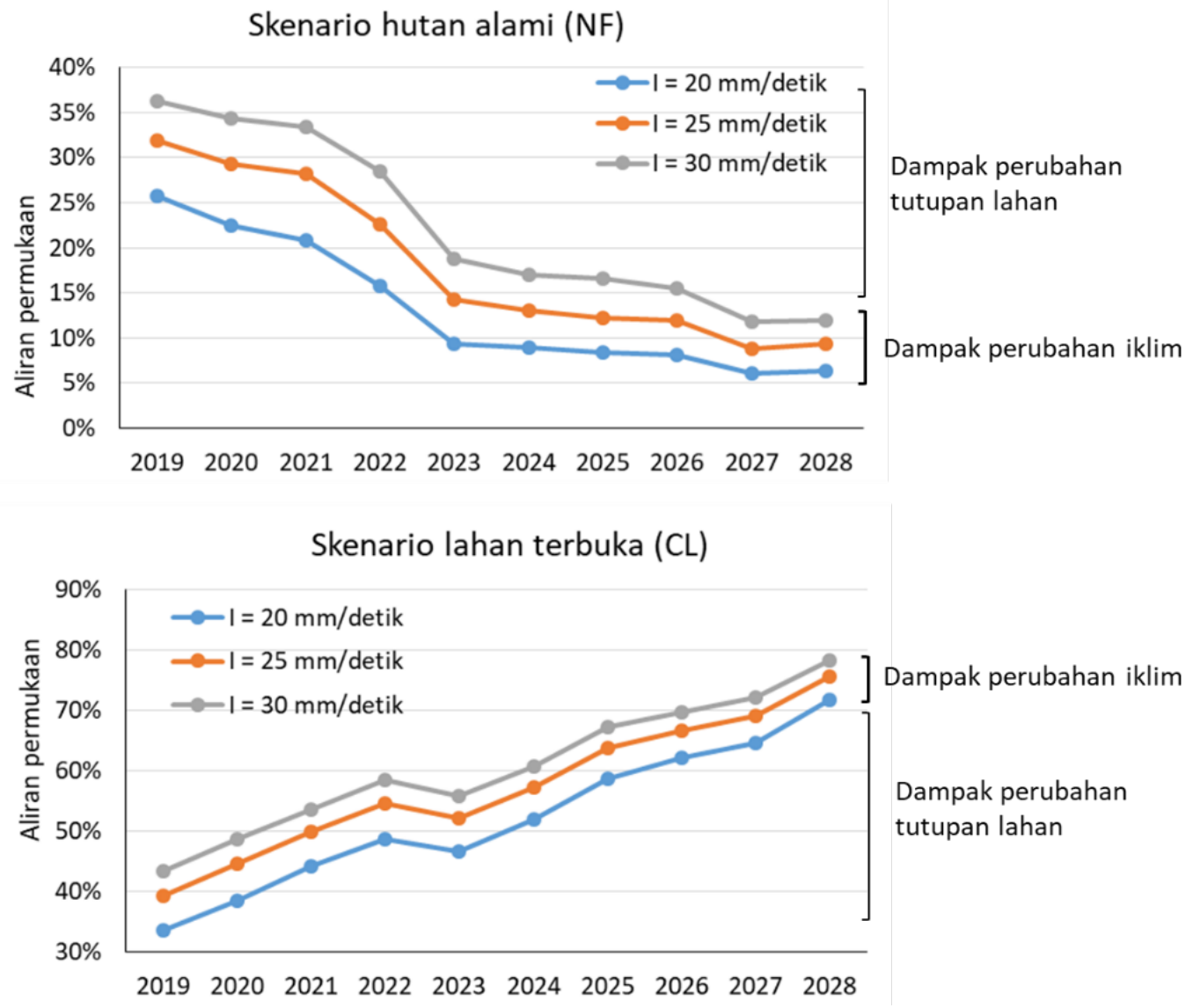

Gambar 16. Simulasi dampak perubahan tutupan lahan dan iklim di DAS Citarum Hulu 2019-2028 


\section{Kesimpulan dan Rekomendasi}

Hasil kalibrasi dan evaluasi menunjukkan bahwa parameterisasi model GenRiver dengan data pengamatan curah hujan dan debit air DAS Citarum Hulu pada periode tahun 2012-2018 berkinerja dengan baik dan memadai untuk digunakan untuk mensimulasikan pengaruh perubahan tutupan lahan dan perubahan iklim terhadap fungsi hidrologis DAS Citarum Hulu. Analisa sensitivitas dengan mesimulasikan rentang perubahan ekstrim positif dan ekstrim negative menunjukkan model cukup sensitif dalam mensimulasikan dampak terhadap neraca air di tingkat bentang lahan dan telah memberikan gambaran mengenai degradasi dan perbaikan fungsi hidrologis yang mungkin terjadi.

Secara umum kondisi saat ini (2012-2018), 35\% curah hujan yang jatuh di dalam DAS Citarum hulu dimanfaatkan sebagai evapotranspirasi oleh vegetasi, 37\% mengalir sebagai aliran permukaan, 7\% menjadi aliran bawah permukaan dan $20 \%$ aliran dasar.

Berdasarkan hasil simulasi model GenRiver (2019-2028), setiap pembukaan lahan 4700 ha menjadi area terbuka akan berkontribusi terhadap kenaikan aliran permukaan sebesar 1\% (dari curah hujan). Sebaliknya untuk menurunkan aliran permukaan sebesar 1\% diperlukan peningkatan area lahan bervegetasi berkayu sebesar 7900 ha.

Kenaikan intensitas curah hujan berkorelasi positif dengan kenaikan aliran permukaan. Semakin tinggi intensitas curah hujan maka semakin tinggi aliran permukaan. Oleh karena itu peningkatan area lahan dengan dominasi vegetasi berkayu dapat manjadi penyangga terhadap kejadian perubahan intensitas curah hujan.

Studi ini disusun dengan menggunakan skenario konseptual yang belum didasarkan pada skema intervensi realistis di tingkat plot maupun tingkat bentang lahan. Langkah selanjutnya yang dapat dilakukan adalah (i) menyusun skenario intervensi yang mungkin dan masuk akal untuk diterapkan di DAS Citarum berdasarkan Diskusi Kelompok Terfokus maupun Interviu Tokoh Kunci yang dilakukan di DAS Citarum Hulu, kemudian (ii) mensimulasikan skenario tersebut menggunakan model GenRiver, untuk Menyusun rekomendasi kebijakan mengenai intervensi penggunaan lahan yang layak diterapkan di DAS Citarum Hulu. 


\section{Daftar Pustaka}

Aldrian E dan Susanto RW. 2003. Identification of three dominant rainfall regions within Indonesia and their relationship to sea surface temperature, Int. J. Climatol 23:1435-1452.

Balai Besar Wilayah Sungai (BBWS) Citarum. 2016. Rencana Pengelolaan Sumber Daya Air Wilayah Sungai Citarum, Jakarta (http://bbwscitarum.com/wpcontent/uploads/2016/11/Rencana-Pengelolaan-Sumber-Daya-Air-WS-Citarum.pdf)

Direktorat Kehutanan dan Konservasi Sumber Daya Air, 2010, Kajian Model Pengelolaan Daerah Aliran Sungai (DAS) Terpadu, jakarta https://www.bappenas.go.id/files/1213/5053/3289/17kajian-model-pengelolaandaerah-aliran-sungai-das-terpadu $20081123002641 \quad 16 . p d f$

Guo H, Hu Q, Jiang T. 2008. Annual and seasonal stream flow responses to climate and land cover changes ini the Poyang lake basin, China. Journal of Hydrology 355:106-122.

Khasanah K, Mulyoutami E, Ekadinata A, Asmawan T, Tanika L, Said Z, van Noordwijk M, dan Leimona B. 2010. A Study of Rapid Hydrological Appraisal in the Krueng Peusangan Watershed, NAD, Sumatra. Working paper nr.123. Bogor, Indonesia: World Agroforestry Centre. 53p.

Kumarasamy K, Belmont P. 2018. Calibration parameter selection and watershed hydrology model evaluation in time and frequency domains. Water 10:710. https://doi:10.3390/w10060710

Kurniasih N. 2002, Pengelolan DAS Citarum Berkelanjutan. Jurnal Teknologi Lingkungan 3(2):82-91.

Moriasi DN, Arnold JG, Van Liew MW, Bingner RL, Harmel RD, Veith TL. 2001. Model Evaluation Guidelines for Systematic Quantification of Accuracy in Watershed Simulations. American Society of Agricultural and Biological Engineers 20(3):885-900.

Peters T. 2016. Climatic Types of Water Balances in the Tropics, in Pancel L, Köhl M (Eds.), Tropical Forestry Handbook. Springer-Verlag Berlin. 3363p.

van Noordwijk M, Widodo RH, Farida A, Suyamto D, Lusiana B, Tanika L, and Khasanah N. 2010. GenRiver and FlowPer: Generic River Flow Persistence Models, User Manual Version 2.0. Bogor, Indonesia: World Agroforestry Centre (ICRAF). 

World Agroforestry is an autonomous, non-profit research organization whose vision is a rural transformation in the developing world as smallholder households increase their use of trees in agricultural landscapes to improve food security, nutrition, income, health, shelter, social cohesion, energy resources and environmental sustainability. The Centre generates science-based knowledge about the diverse roles that trees play in agricultural landscapes, and uses its research to advance policies and practices, and their implementation that benefit the poor and the environment. It aims to ensure that all this is achieved by enhancing the quality of its science work, increasing operational efficiency, building and maintaining strong partnerships, accelerating the use and impact of its research, and promoting greater cohesion, interdependence and alignment within the organization.

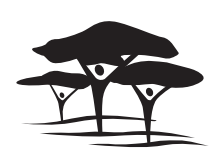

United Nations Avenue, Gigiri • PO Box 30677 • Nairobi, $00100 \cdot$ Kenya Telephone: +254207224000 or via USA +1 6508336645 Fax: +254207224001 or via USA +1 6508336646 Email: worldagroforestry@cgiar.org•www.worldagroforestry.org

Southeast Asia Regional Program • Sindang Barang • Bogor 16680 PO Box $161 \cdot$ Bogor $16001 \cdot$ Indonesia

Telephone: +62 $2518625415 \cdot$ Fax: +62 2518625416

Email: icraf-indonesia@cgiar.org•www.worldagroforestry.org/region/SEA 